\title{
Synthesis, biological activity and molecular modeling of new biphenylic carboxamides as potent and selective $\mathrm{CB} 2$ receptor ligands
}

Simone Bertini, ${ }^{a *}$ Teija Parkkari, ${ }^{b, c}$ Juha R. Savinainen, ${ }^{c}$ Chiara Arena, ${ }^{a}$ Giuseppe Saccomanni, ${ }^{a}$ Simone Saguto, ${ }^{a}$ Alessia Ligresti, ${ }^{d}$ Marco Allară, ${ }^{d}$ Agostino Bruno, ${ }^{e}$ Luciana Marinelli, ${ }^{e}$ Vincenzo Di Marzo, ${ }^{d}$ Ettore Novellino, ${ }^{e}$ Clementina Manera,${ }^{a}$ Marco Macchia ${ }^{a}$

apipartimento di Farmacia, Università di Pisa, Via Bonanno 6, 56126 Pisa, Italy.

${ }^{b}$ University of Eastern Finland, Faculty of Health Sciences, School of Pharmacy, POBox 1627, 70211 Kuopio, Finland.

'University of Eastern Finland, Faculty of Health Sciences, Institute of Biomedicine, School of Medicine, POBox 1627, 70211 Kuopio, Finland.

${ }^{\mathrm{d} E n d o c a n n a b i n o i d ~ R e s e a r c h ~ G r o u p, ~ I s t i t u t o ~ d i ~ C h i m i c a ~ B i o m o l e c o l a r e, ~ C o n s i g l i o ~ N a z i o n a l e ~ d e l l e ~}$ Ricerche, Via Campi Flegrei 34, 80078 Pozzuoli, Napoli, Italy.

'Dipartimento di Farmacia, Università di Napoli “Federico II", Via D. Montesano 49, 80131 Napoli, Italy.

*To whom correspondence should be addressed. S.B.: phone, +39(0)502219579; fax, +39(0)502219605; e-mail: simone.bertini@ farm.unipi.it.

RECEIVED DATE (to be automatically inserted after your manuscript is accepted if required according to the journal that you are submitting your paper to) 


\section{Highlights}

- We report the study of a series of biphenylic carboxamides as new CB2 ligands.

- Good CB2 affinity/selectivity was reached with some 3-n-butyl-substituted compounds.

- The 3-n-butyl-substituted compounds proved to be CB2 neutral antagonists. 


\section{Graphical Abstract}
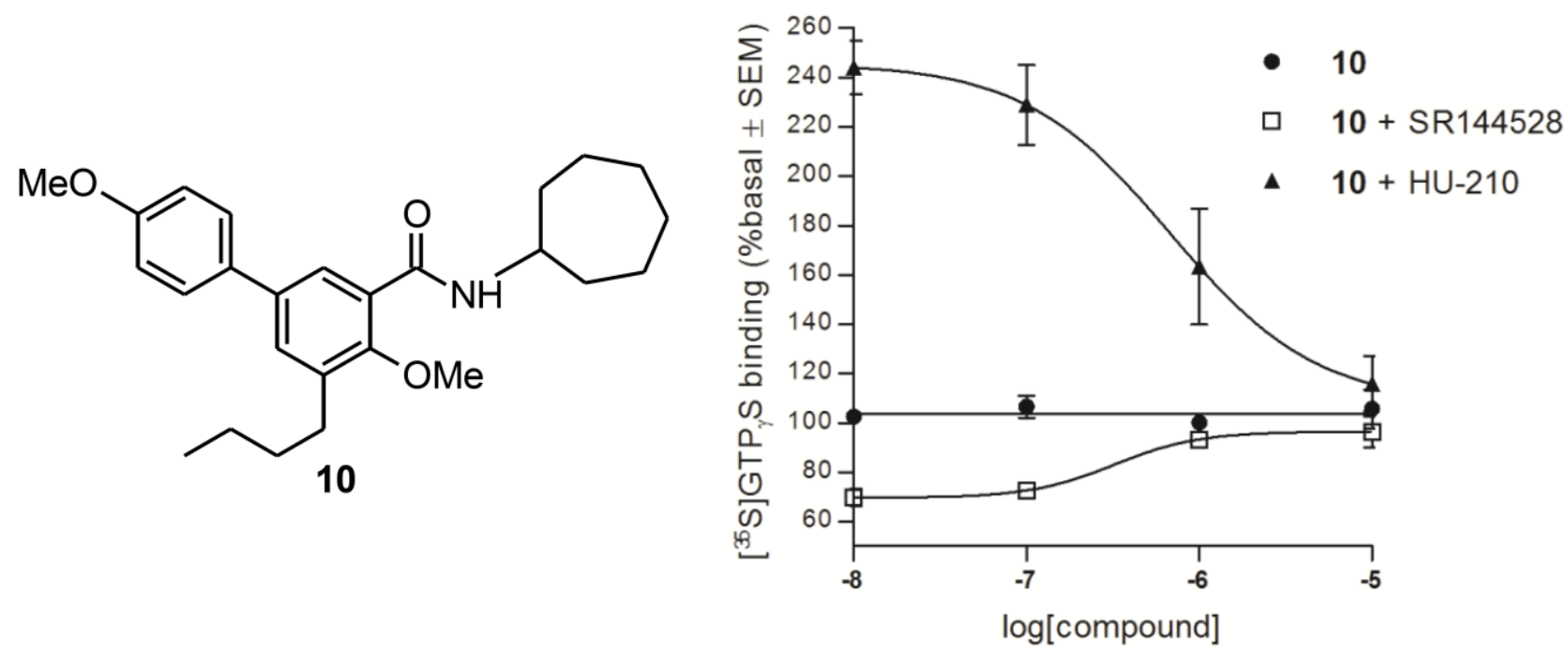

\section{3-n-butyl-substituted biphenyl carboxamides:}

Potent and selective CB2 receptor neutral antagonists 


\begin{abstract}
The CB2 receptor is a therapeutic target of increasing importance for several diseases, including pain, inflammation, neurodegeneration, cancer, and osteoporosis. While several compounds showing CB2selective agonist or inverse agonist properties have been developed, only few $\mathrm{CB} 2$ receptor selective neutral antagonists are actually known. Such type of compounds could be useful to study more in depth the role of the CB2 receptor, because they lack the ability to counteract its "constitutive" activity. Here we describe the synthesis and biological activity of a series of biphenylic carboxamides as a new class of $\mathrm{CB} 2$ receptor selective ligands. In binding assays, one of these compounds showed good CB2 receptor affinity and selectivity $\left(K_{\mathrm{i}}=11.48 \mathrm{nM}\right.$; Selectivity Index $\left.=130\right)$. Furthermore, in functional assays, the same compound showed a very interesting pharmacological profile as $\mathrm{CB} 2$ receptor selective neutral antagonist. These results pave the way to further developments, including structural optimization, with the aim to obtain more potent CB2 receptor ligands with this peculiar feature.
\end{abstract}

\title{
1. Introduction
}

The two cannabinoid receptors $\mathrm{CB} 1$ and $\mathrm{CB} 2$ belongs to the superfamily of $\mathrm{G}$ protein-coupled receptors (GPCRs) and constitute, together with their endogenous ligands (endocannabinoids) and the enzymes regulating their tissue levels, the so called endocannabinoid system (ECS) $[1,2]$. The CB1 receptors are mainly located at the terminals of central and peripheral neurons where they mediate the inhibition of the release of various neurotransmitters [2, 3]. However, it has also been found in other, non-neuronal, peripheral tissues [1]. The CB2 receptors are mainly expressed in immune cells and tissues where it modulates cytokine release and immune cell migration [4]. Its expression has also been highlighted in other types of cells, such as some central and peripheral neurons [5], vascular endothelial 
cells, vascular smooth muscle, cardiomyocytes, osteoblasts, and osteoclasts [6]. Compounds that can activate cannabinoid receptors present a wide range of therapeutic applications $[4,7]$ : three licensed medicines containing nonselective $\mathrm{CB} 1 / \mathrm{CB} 2$ receptor agonists are in use in the clinic to ameliorate the chemotherapy-induced nausea and vomiting $\left(\mathrm{Cesamet}^{\circledR}\right.$ and Marinol $\left.^{\circledR}\right)$, stimulation of appetite e.g. in AIDS patients (Marinol ${ }^{\circledR}$ ) and relief of neuropathic/cancer pain or management of spasticity in multiple sclerosis $\left(\right.$ Sativex $\left.^{\circledR}\right)[1,4,8]$; other potential therapeutic applications of CB1/CB2 agonists include epilepsy, anxiety, depression, Parkinson's disease, Huntington's disease, amyotrophic lateral sclerosis, stroke, cancer, glaucoma, hepatic and intestinal disorders [7, 8].

The major limitation in the therapeutic use of non-selective cannabinoid agonists is the occurrence of psychotropic effects, which are thought to be mediated almost exclusively by the activation of the central $\mathrm{CB} 1$ receptors [9]; therefore selectively targeting the $\mathrm{CB} 2$ receptor is one of the proposed strategies to avoid these effects and improve the benefit-to-risk ratio of such molecules [4, 10]. Besides, there are recent evidence indicating the important role of the CB2 receptors in pathologies involving an inflammatory component (such as neurodegenerative disorders [11, 12], inflammatory bowel disease [13] and atherosclerosis [14]), osteoporosis [15, 16], and cancer [17, 18]. Furthermore, recent studies highlight the involvement of the CB2 receptors in alleviating pain $[19,20]$.

Noteworthy, in preclinical studies, analgesic and anti-inflammatory properties have been described for both $\mathrm{CB} 2$ receptor agonists [21, 22] and CB2 receptor inverse agonists [23, 24]. A similar trend can be evidenced regarding bone remodeling and osteoporosis [25-28]. Taken together, these findings support the fact that $\mathrm{CB} 2$ receptor pharmacology deserves further studies to better understand its role in pathophysiological conditions.

There is also a considerable interest in the development of potent $\mathrm{CB} 2$ receptor neutral antagonists: high-affinity ligands that lack significant agonist or inverse agonist action. Actually, a very few compounds having such characteristics have been described [29, 30]. In a biological system expressing 
CB2 receptor, a CB2 receptor neutral antagonist could be useful as a pharmacological "tool" to distinguish between tonic activity arising from endocannabinoid release (which it should oppose) and tonic "constitutive" activity of CB2 receptor (which it should not oppose) [31].

In this context, we have recently developed a series of 1,2-dihydro-2-oxo-pyridine-3-carboxamides (general structure A, Figure 1) with high CB2 receptor affinity and selectivity [32]. We found that the functional activity of these compounds was greatly influenced by the substituent in position 5 of the 2 oxo-pyridine nucleus: in particular, the $N$-cycloheptyl-1-[(4-fluorophenyl)methyl]-2-oxo-1,2dihydropyridine-3-carboxamide proved to be a CB2 receptor agonist whereas the 5-( $p$ methoxy)phenyl-substituted analogue showed a behaviour as CB2 receptor neutral antagonist/weak partial CB2 receptor inverse agonist [32]. In this work we report the synthesis and the biological activity of a new class of biphenylic $\mathrm{CB} 2$ receptor ligands, structurally derived from the previously reported 5-substituted type A-derivatives, in which the 2-oxo-pyridine nucleus was replaced by a 2 methoxy-phenyl scaffold (general structure B, Figure 1).

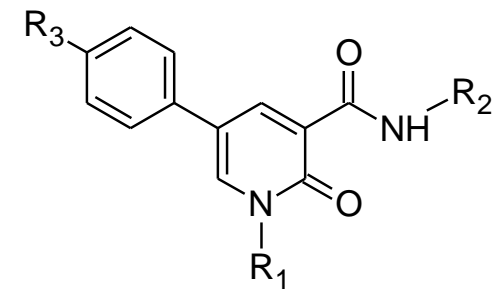

(A)

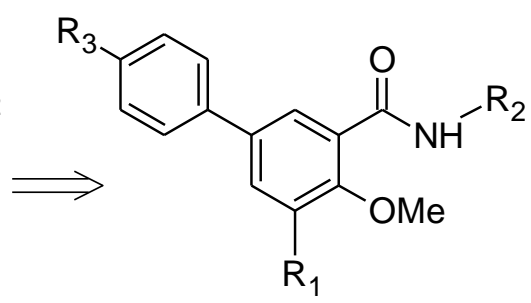

(B)

Figure 1. Biphenylic compounds (B) structurally derived from 5-substituted-1,2-dihydro-2-oxopyridine-3-carboxamides (A).

In particular, we herein described a series of biphenylic derivatives (compounds 1-12, Table 1) in which the substituent on the carboxamide moiety $\left(\mathrm{R}_{2}\right)$ was a cycloheptyl or a 4-methylcyclohexyl; the 
4-substituent on the peripheral phenyl ring $\left(\mathrm{R}_{3}\right)$ was an hydrogen, a fluorine or a methoxy group and the substituent at position $3\left(\mathrm{R}_{1}\right)$ was a methyl or a $n$-butyl group. The new compounds were tested on membranes prepared from HEK-293 cells expressing the human CB1 and CB2 receptor, to determine their affinities towards both subtypes of $\mathrm{CB}$ receptors. Functional $\mathrm{CB}$ receptor activity was also investigated for five new biphenylic compounds by the GTP $\gamma \mathrm{S}$ binding assay. Finally, a molecular modelling study was accomplished to highlights the interactions of this type of compounds with CB receptors binding cavity.

\section{Chemistry}

Compounds 1-9 were synthesized as shown in Scheme 1. The commercial 3-methylsalicylic acid 13 was converted into the corresponding methyl ester 14 upon treatment with dimethyl sulphate in the presence of potassium carbonate and tetrabutylammonium bromide in water/dichloromethane [33]. Compound 14 was then submitted to iodination using sodium iodide, sodium hydroxide and sodium hypochlorite in water [33]. The subsequent treatment of the resulting intermediate 15 with dimethyl sulphate and sodium hydroxide in the presence of tetrabutylammonium bromide in water/dichlorometane [33] afforded the derivative 16 which, submitted to a Pd-catalyzed crosscoupling reaction in the Suzuki conditions using the appropriate arylboronic acid (phenylboronic, $p$ methoxyphenylboronic, $p$-fluorophenylboronic acid) [34], yielded the intermediates 17-19. Alkaline hydrolysis [35] of these compounds afforded the corresponding carboxylic acids 20-22 which were treated with thionyl chloride and then with cycloheptylamine or 4-methylcyclohexylamine (cis/trans mixture) [36] obtaining the final products 1-9. Regarding compounds 4/5, 6/7 and 8/9, the cis and trans isomer were separated by flash chromatography on silica gel column. The two isomers were identified 
on the basis of the chemical shift of the proton in the $\alpha$ position respect to the amino group on the 1amino-4-methylcyclohexane ring. In the $c i s$ isomer this proton resonates at higher ppm ( $\delta$ from 4.33 to $4.36 \mathrm{ppm}$ ) compared to the same proton in the trans isomer ( $\delta$ from 3.90 to $4.00 \mathrm{ppm}$ ). This can be explained by diamagnetic anisotropy of the $\mathrm{C}-\mathrm{C}$ single bond in cyclohexane systems, considered as a "prolate" ellipse with transverse susceptibility greater than longitudinal susceptibility $\left(X_{T}>X_{L}\right)$. In the cis isomer, the proton in the $\alpha$ position respect to the nitrogen atom is located in equatorial position (deshielded zone) resonating at lower fields; in the trans isomer, the proton is in the axial position (shielded zone) resonating at higher fields [37].<smiles>Cc1cccc(C(=O)O)c1O</smiles>

13<smiles>COC(=O)c1cccc(C)c1O</smiles>

14<smiles>COC(=O)c1cc(I)cc(C)c1O</smiles>

15<smiles>COC(=O)c1cc(I)cc(C)c1OC</smiles>

16<smiles>[R5]c1ccc(-c2cc([C])c(OC)c(C(=O)O)c2)cc1</smiles>

20: $\mathrm{R}=\mathrm{H}$

21: $R=O M e$

22: $R=F$<smiles>[R5]c1ccc(-c2cc(C)c(OC)c(C(=O)OC)c2)cc1</smiles>

17: $\mathrm{R}=\mathrm{H}$

18: $\mathrm{R}=\mathrm{OMe}$

19: $R=F$ 
Scheme 1. Reagents and conditions: a) TBAB, $\left(\mathrm{CH}_{3}\right)_{2} \mathrm{SO}_{4}, \mathrm{~K}_{2} \mathrm{CO}_{3}, \mathrm{H}_{2} \mathrm{O}, \mathrm{CH}_{2} \mathrm{Cl}_{2}, \mathrm{RT}, 4 \mathrm{~h}$; b) NaI, $\mathrm{NaOH}$, aq. $\mathrm{NaClO}, \mathrm{MeOH}, 0-3^{\circ} \mathrm{C}, 4.5 \mathrm{~h} ;$ c) TBAB, $\left(\mathrm{CH}_{3}\right)_{2} \mathrm{SO}_{4}$, aq. $\mathrm{NaOH}, \mathrm{CH}_{2} \mathrm{Cl}_{2}, \mathrm{RT}$, overnight; d) Suitable arylboronic acid, $\mathrm{Pd}(\mathrm{OAc})_{2}, \mathrm{PPh}_{3}$, aq. $\mathrm{Na}_{2} \mathrm{CO}_{3}$, toluene, $85^{\circ} \mathrm{C}$, overnight; e) $\mathrm{KOH}, \mathrm{MeOH}, 75$ ${ }^{\circ} \mathrm{C}, 19 \mathrm{~h}$; f) 1) $\mathrm{SOCl}_{2}$, reflux, 30 min.; 2) Suitable cycloalkylamine, $\mathrm{CH}_{2} \mathrm{Cl}_{2}$, $\mathrm{RT}$, overnight.

Compounds 10-12 were synthesized according to Scheme 2. The commercial 3-bromo-2methoxybenzoic acid $\mathbf{2 3}$ was converted in the corresponding methyl ester $\mathbf{2 4}$, using methanol and concentrated sulphuric acid. Subsequently, a cross-coupling reaction with $n$-butylboronic acid in the presence of $\quad$ bis(dibenzylideneacetone)palladium( 0$), \quad 1,2,3,4,5$-pentaphenyl-1'-(di-tertbutylphosphino)ferrocene (Q-phos) and tribasic potassium orthophosphate in anhydrous toluene [38] allowed to obtain the intermediate 25. This was then brominated using bromine in chloroform [39], affording not only the derivative $\mathbf{2 6}$, but also a significant amount of the demethylated bromide $\mathbf{2 7}$ which was converted again in the compound $\mathbf{2 6}$ upon treatment with dimethyl sulphate and sodium hydroxide in the presence of tetrabutylammonium bromide in water/dichloromethane [33]. Compound 27 was then submitted to a Suzuki reaction with $p$-methoxyphenylboronic acid, aqueous sodium carbonate, palladium acetate and triphenylphosphine in methanol/toluene [34], obtaining the intermediate $\mathbf{2 8}$ which was hydrolysed (potassium hydroxide in methanol [35]) leading to the acid 29. Treatment with thionyl chloride and subsequently with the suitable cycloalkylamine in dichloromethane [36] allowed to obtain the desired final products 10-12. Also in this case the cis (11) and trans (12) isomer were separated by flash chromatography on silica gel column. 
<smiles>COc1c(Br)cccc1C(=O)O</smiles>

23<smiles>COC(=O)c1cccc(Br)c1OC</smiles>

24<smiles>CCCCc1cccc(C(=O)OC)c1OC</smiles>

25<smiles>CCCCc1cc(-c2ccc(OC)cc2)cc(C(=O)OC)c1OC</smiles>

28<smiles>COc1ccc(-c2cc(OC)c(OC)c(C(=O)O)c2)cc1</smiles>

29<smiles>[R]NC(=O)c1cc(-c2ccc(OC)cc2)cc(OCC)c1OC</smiles>

10-12

Scheme 2. Reagents and conditions: a) TBAB, $\left(\mathrm{CH}_{3}\right)_{2} \mathrm{SO}_{4}, \mathrm{~K}_{2} \mathrm{CO}_{3}, \mathrm{H}_{2} \mathrm{O}, \mathrm{CH}_{2} \mathrm{Cl}_{2}, \mathrm{RT}, 4 \mathrm{~h}$; b) $\mathrm{NaI}$, $\mathrm{NaOH}$, aq. $\mathrm{NaClO}, \mathrm{MeOH}, 0-3^{\circ} \mathrm{C}, 4.5 \mathrm{~h} ;$ c) TBAB, $\left(\mathrm{CH}_{3}\right)_{2} \mathrm{SO}_{4}$, aq. $\mathrm{NaOH}, \mathrm{CH}_{2} \mathrm{Cl}_{2}$, RT, overnight; d) Suitable arylboronic acid, $\mathrm{Pd}(\mathrm{OAc})_{2}, \mathrm{PPh}_{3}$, aq. $\mathrm{Na}_{2} \mathrm{CO}_{3}$, toluene, $90^{\circ} \mathrm{C}$, overnight; e) $\mathrm{KOH}, \mathrm{MeOH}, 75$ ${ }^{\circ} \mathrm{C}, 19$ h; f) 1) $\mathrm{SOCl}_{2}$, reflux, 30 min.; 2) Suitable cycloalkylamine, $\mathrm{CH}_{2} \mathrm{Cl}_{2}$, $\mathrm{RT}$, overnight.

\section{Results and discussion}

\section{1. $C B 1$ and $C B 2$ receptor affinity}

The binding affinities ( $K_{\mathrm{i}}$ values) of the compounds 1-12 were evaluated by competitive binding assays against $\left[{ }^{3} \mathrm{H}\right] \mathrm{CP}-55,940$ using membranes from HEK-293 cells overexpressing the human recombinant 
$\mathrm{CB} 1$ receptor and $\mathrm{CB} 2$ receptor, as previously described [32]. The results are reported in Table 1 with the $K_{\mathrm{i}}$ values of the reference compounds SR144528 and JWH133. The new biphenylic compounds exhibit in general higher affinity for the CB2 than for the CB1 receptor, in agreement with results obtained for the previously developed series of compounds [32].

In general, we can point out that, regarding to the structural modifications at the position $3\left(\mathrm{R}_{1}\right)$ of the central phenyl ring, the introduction of a $n$-butyl group (compounds 10-12) gave better results, in terms of $\mathrm{CB} 2$ receptor affinity and $\mathrm{CB} 2$ receptor selectivity, than the introduction of a methyl group (compounds 1-9).

Among the 3-methyl-substituted compounds (1-9), the presence of a $p$-methoxy group in the peripheral phenyl ring (compounds 1-3) led to low levels of CB2 receptor affinity (400 nM $<K_{\mathrm{i}}<610 \mathrm{nM}$ ), although these compounds did not show an appreciable affinity towards the CB1 receptor $\left(K_{\mathrm{i}}>10000\right.$ $\mathrm{nM}$ ); when the $p$-methoxy group was replaced by an hydrogen atom (compounds 4-6), binding properties were improved, although the $K_{\mathrm{i}}$ values resulted not exciting (90-150 nM for CB2 receptor); the introduction of a $p$-fluoro group (compounds 7-9) led to a maintenance or a slight improvement of the $\mathrm{CB} 2$ receptor affinity, with $K_{\mathrm{i}}$ values in the range of $60-90 \mathrm{nM}$. The substituent on the carboxamide moiety $\left(\mathrm{R}_{2}\right)$ did not significantly influence the affinity of the 3-methyl-substituted biphenylic derivatives. In fact, the presence of a cycloheptyl or a 4-methylcyclohexyl group, maintaining the same substituents in the other positions (compounds 1-3; 4-6; 7-9), led only to small changes in the CB2 receptor affinity values. The CB2 receptor selectivity levels of the 3-methyl-substituted compounds were generally found to be in the middle range (S. I. of 3-9), with exception of the noteworthy result of compound 5 (S. I. = 17).

The 3-n-butyl-substituted derivatives (10-12) provided much better results. Compound 10, bearing a $p$ methoxy substituent on the peripheral aromatic ring and a cycloheptyl on the carboxamide, showed very good levels of CB2 receptor affinity $\left(K_{\mathrm{i}}(\mathrm{CB} 2)=11.48 \mathrm{nM} ; K_{\mathrm{i}}(\mathrm{CB} 1)=1494 \mathrm{nM}\right)$ and selectivity 
$(\mathrm{S} . \mathrm{I} .=130)$, resulting to be the most affine and selective compound of the series. The introduction of a cis-4-methylcyclohexyl group on the carboxamide (compound 12), however, led to good binding properties, albeit with a slightly decrement in $\mathrm{CB} 2$ receptor affinity $\left(K_{\mathrm{i}}(\mathrm{CB} 2)=22 \mathrm{nM} ; K_{\mathrm{i}}(\mathrm{CB} 1)=\right.$ $1550 \mathrm{nM}$ ) and selectivity (S. I. $=70$ ) respect to compound 10. A more marked drop in the binding properties was found by introducing a trans-4-methylcyclohexyl group on the carboxamide, as in compound 11, showing a $K_{\mathrm{i}}$ on CB2 receptor of $143 \mathrm{nM}$ and a S. I. of 16 . Interestingly, in the 3-nbutyl-substituted series (compounds 10-12), the substituent on the carboxamide had a significant influence on the binding properties - unlike the 3-methyl-substituted series (see above) - being the cycloheptyl the best one. Furthermore, replacing the cycloheptyl with a 4-methylcyclohexyl, the absolute configuration of the $\mathrm{C} 1$ and $\mathrm{C} 4$ carbons seems to be important for the binding, given the marked difference in affinity and selectivity between the cis-isomer (12) and the trans-isomer (11). 
Table 1. Radioligand binding data of biphenylic derivatives. ${ }^{a}$<smiles>[R]NC(=O)c1cc(-c2ccc(Br)cc2)cc([R])c1OC</smiles>

$K_{\mathrm{i}}(\mathrm{nM})$

\begin{tabular}{lllllll}
\hline Compound & $\mathrm{R}_{1}$ & $\mathrm{R}_{2}$ & $\mathrm{R}_{3}$ & $\mathrm{CB}^{\mathrm{b}}$ & $\mathrm{CB}^{\mathrm{c}}$ & S.I. $^{\mathrm{d}}$ \\
\hline $\mathbf{1}$ & methyl & cycloheptyl & methoxy & $>10000$ & $>10000$ & 1 \\
$\mathbf{2}$ & methyl & trans-4-methylcyclohexyl & methoxy & $>10000$ & $>10000$ & 1 \\
$\mathbf{3}$ & methyl & cis-4-methylcyclohexyl & methoxy & $>10000$ & $>10000$ & 1 \\
$\mathbf{4}$ & methyl & cycloheptyl & $\mathrm{H}$ & 870 & 100 & 8.7 \\
$\mathbf{5}$ & methyl & trans-4-methylcylclohexyl & $\mathrm{H}$ & 1530 & 90 & 17 \\
$\mathbf{6}$ & methyl & cis-4-methylcyclohexyl & $\mathrm{H}$ & 1090 & 150 & 7.27 \\
$\mathbf{7}$ & methyl & cycloheptyl & $\mathrm{F}$ & 160 & 60 & 2.67 \\
$\mathbf{8}$ & methyl & trans-4-methylcyclohexyl & $\mathrm{F}$ & 620 & 90 & 6.89 \\
$\mathbf{9}$ & methyl & cis-4-methylcyclohexyl & $\mathrm{F}$ & 180 & 60 & 3 \\
$\mathbf{1 0}$ & $n$-butyl & cycloheptyl & methoxy & 1494 & 11.48 & 130 \\
$\mathbf{1 1}$ & $n$-butyl & trans-4-methylcyclohexyl & methoxy & 2294 & 143 & 16 \\
$\mathbf{1 2}$ & $n$-butyl & cis-4-methylcyclohexyl & methoxy & 1550 & 22 & 70 \\
SR144528 & & & & 437 & 0.6 & 728 \\
$J W H 133$ & & & & 677 & 3 & 226
\end{tabular}

${ }^{a}$ Data represent mean values for at least three separate experiments performed in duplicate and are expressed as $K_{\mathrm{i}}(\mathrm{nM})$, for $\mathrm{CB} 1$ and $\mathrm{CB} 2$ receptor binding assays. Standard error of means (SEM) are not shown for the sake of clarity and were never higher than $5 \%$ of the means. ${ }^{\mathrm{b}}$ Affinity of compounds for CB1 receptor was evaluated using membranes from HEK-293 cells transfected and $\left[{ }^{3} \mathrm{H}\right] \mathrm{CP} 55,940$. ${ }^{\mathrm{c}}$ Affinity of compounds for CB2 receptor was evaluated using membranes from HEK-293 cells transfected and $\left[{ }^{3} \mathrm{H}\right] \mathrm{CP}-55,940 . \mathrm{SI}^{\mathrm{d}}$ : selectivity index for $\mathrm{CB} 2$ receptor calculated as $K_{\mathrm{i}}(\mathrm{CB} 1) / K_{\mathrm{i}}(\mathrm{CB} 2)$ ratio. 


\section{2. $C B 1$ and $C B 2$ receptor functional activity}

$\mathrm{CB} 1$ and $\mathrm{CB} 2$ receptor activities of the compounds $\mathbf{7}$ and $\mathbf{9 - 1 2}$ were evaluated by the $\left[{ }^{35} \mathrm{~S}\right] \mathrm{GTP} \gamma \mathrm{S}$ binding assay, essentially as previously described [29, 40]. In the current study, compounds 7 and 9 were found equally potent full agonists $\left(-\log \mathrm{EC}_{50}=6.4 \pm 0.1,-\log \mathrm{EC}_{50}=6.5 \pm 0.1, \mathrm{n}=3\right)$ in stimulating receptor-mediated $\mathrm{G}$ protein activity in membranes prepared from human $\mathrm{CB} 2$-transfected $\mathrm{CHO}$-cells (Figure 2A). Both compounds were found silent when tested in mock-transfected-cell membranes confirming further that the responses were CB2-mediated. Compounds $\mathbf{7}$ and $\mathbf{9}$ were not able to stimulate CB1-mediated G protein-activity at rat cerebellar membranes with concentrations below 10 $\mu \mathrm{M}$, but were slightly attenuating agonist response (HU210, $1 \mathrm{nM}$ ) at $10 \mu \mathrm{M}$. Similar but more potent antagonist activity at CB1 was observed with the compounds 10-12 which all dose-dependently antagonized HU-210 (1 nM) -stimulated activity (Figure 2B). In preliminary experiments with CB2 receptor, we observed that the structurally similar compounds $\mathbf{1 0 - 1 2}$ were able to reverse HU-210stimulated responses, but alone the compounds were silent. To evaluate ligand-activity of this kind in more detail, we chose the compound $\mathbf{1 0}$ for further analysis. We found that even though the compound $\mathbf{1 0}$ is a silent ligand at $\mathrm{CB} 2$ receptor, it is able to antagonize half-maximal responses of the agonist (HU-210, $1 \mathrm{nM}$ ) and an inverse CB2 agonist (SR144528, $3 \mathrm{nM}$ ) (Figure 2C) dose-dependently, indicating that it is a neutral CB2 antagonist. To examine further whether the antagonism is competitive or non-competitive, we determined inhibition of the agonist dose-responses with increasing concentrations of $\mathbf{1 0}$ and used Schild-plot fitting for the further analysis (Figure 2D). Maximal agonist responses were not altered with increasing concentrations of the compound $\mathbf{1 0}$ implicating that the compound would be a competitive antagonist (pA2-value 6.1) (Figure 2D). However, as the slope from the plot appeared relatively gentle $(0.65 \pm 0.05)$, the compound $\mathbf{1 0}$ may rather represent a noncompetitive antagonist at CB2 receptor (the slope for classical competitive antagonists should not differ from the unity [41]). 
A

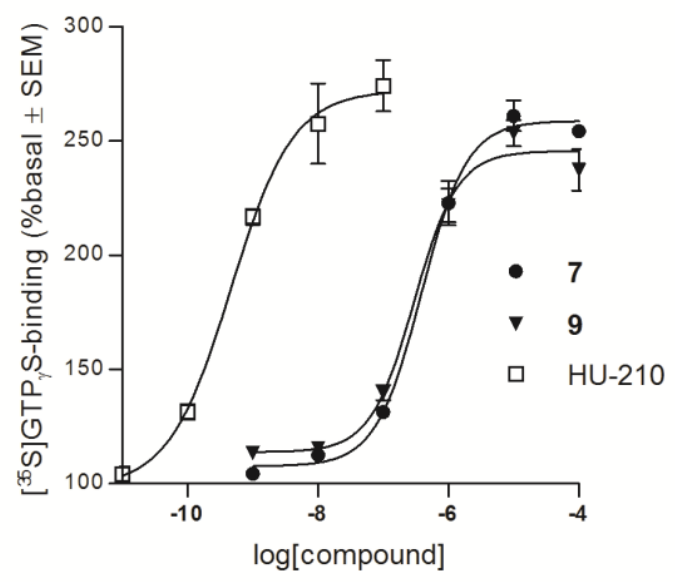

$\mathrm{C}$

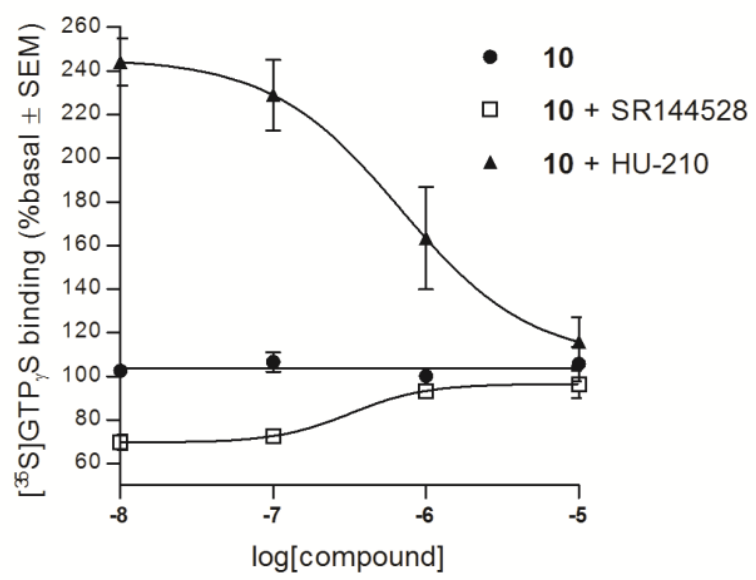

B

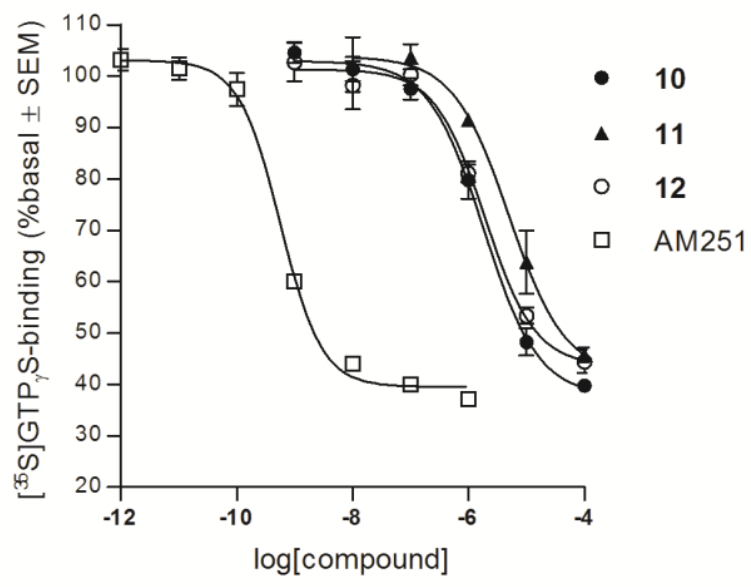

$\mathrm{D}$

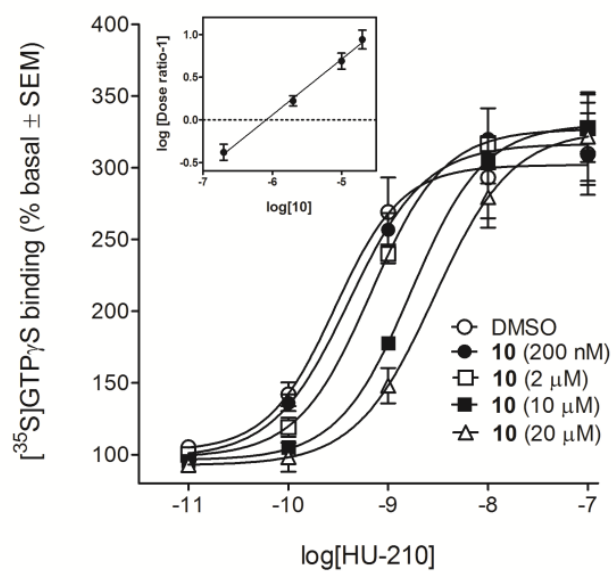

Figure 2. (A) Compounds 7 and 9 are less potent than HU-210 but are full agonists in evoking human CB2 receptor-mediated responses in membranes prepared from stably transfected $\mathrm{CHO}$ cells. (B) Compounds 10, 11 and 12 are CB1 receptor antagonists inhibiting agonist response (HU-210, $1 \mathrm{nM})$ at rat cerebellar membranes. (C) Compound 10 is a neutral CB2 receptor antagonist that dose-dependently reverses both agonist (HU-210, $1 \mathrm{nM}$ ) and inverse agonist (SR144528, $3 \mathrm{nM}$ ) responses at human CB2 receptor. (D) Compound $\mathbf{1 0}$ dose-dependently antagonizes dose-responses to HU-210 (without attenuating maximal agonist response) at $\mathrm{CB} 2$ receptor having calculated $\mathrm{pA}_{2}$-value 6.1 based on the 
Schild-plot (an inset plot). The gentle slope $(0.65 \pm 0.05)$ is statistically differing from the unity (unpaired t-test, $\mathrm{p}<0.05$ ) indicating that the compound $\mathbf{1 0}$ is a non-competitive antagonist. The results are at from least three separate experiments performed in duplicates.

\subsection{Molecular modelling studies}

To rationalize SARs displayed by compounds 4-12 (Table 1), three-dimensional models of both CB1 and CB2 receptors were generated, as previously reported by us [42], by means of Modeller 9.11 software. Basically, the sphingoshine-1-phosphate type 1 receptor [S1P1 (PDB code: 3V2Y)] was used as template because of both, the sequence identity percentage $(27.03 \%$ and $24.16 \%$ for $\mathrm{CB} 1$ and $\mathrm{CB} 2$, respectively) and the close evolutionary relationship [43] (see Material and Methods).

For docking purpose, a box encompassing the entire CB2 orthosteric binding pocket [44-47] was applied. The inverse agonist SR144528, the full agonist $N$-cycloheptyl-1-[(4-fluorophenyl)methyl]-2oxo-1,2-dihydropyridine-3-carboxamide previously reported by us [32], and all compounds reported in Table 1, were docked by means of Glide of Maestro 9.1 suite. As regards docking of SR144528, the selected binding mode resulted in a pose (Figure 3a) in good agreement with that previously reported for the same compound, [46] where the carboxamide oxygen h-bonds to both $\mathrm{K}^{3.28}$ and $\mathrm{S}^{2.60}$, the pyrazole ring $\mathrm{N} 2$ atom h-bonds to the $\mathrm{S}^{7.39}$ side chain, the 3-methyl-4-chloro-phenyl establishes hydrophobic contacts with $\mathrm{T}^{3.33}$ and $\mathrm{W}^{5.43}$ residues, and the $p$-methyl-benzyl moiety forms further hydrophobic contacts with TM6 residues $\left(\mathrm{V}^{6.51}, \mathrm{~L}^{6.54}, \mathrm{M}^{6.55}\right)$. Docking of the N-cycloheptyl-1-[(4fluorophenyl)methyl]-2-oxo-1,2-dihydropyridine-3-carboxamide derivative [32] showed a slight different binding mode (Figure $3 \mathrm{~b}$ ), which allows interaction with $\mathrm{K}^{3.28}$ by the carboxamide oxygen and with $S^{7.39}$ by the 2-oxo group, but not with $S^{2.60}$ (Figure $3 b$ ). A three-dimensional superposition of the two binding modes (Figure 3b) led one to think that the occupancy of the region defined by TM3-5 is fundamental for the ligands functional behavior. Indeed, SR144528 carrying a third aromatic ring 
occupies the cleft defined by TM3-5, while the $N$-cycloheptyl-1-[(4-fluorophenyl)methyl]-2-oxo-1,2dihydropyridine-3-carboxamide compound (full agonist), being smaller, is not able to occupy the aforementioned CB2 receptor cleft (Figure 3b). Thus, that would be the case where functionally different GPCR ligands can share a related binding mode [48]. As regards the novel compounds here reported, when 10 was docked, similarly to the $N$-cycloheptyl-1-[(4-fluorophenyl)methyl]-2-oxo-1,2dihydropyridine-3-carboxamide compound, it interacts with $\mathrm{K}^{3.28}$ and $\mathrm{S}^{7.39}$ residues (Figure 3c). However, differently from the full agonist, $\mathbf{1 0}$ perfectly fills, with its $p$-methoxyphenyl group the TM35 cleft establishing a T-shaped interaction with $\mathrm{W}^{5.43}$. According to the binding mode reported for $\mathbf{1 0}$, structural modification of the position $3\left(\mathrm{R}_{1}\right)$ lead to compounds with increased affinity and selectivity toward CB2 receptor (see Table 1, compounds 1-9 vs. 10-12). The increased CB2 receptor affinity, of the $n$-butyl containing compounds (10-12) with respect to the methyl containing ones (4-9) can be explained by an increased number of hydrophobic contacts by $n$-butyl group with the TM6 hydrophobic residues. On the other hand, the increased CB2 receptor selectivity of compounds 10-12 can be explained by the fact that the $\mathrm{CB} 2 \mathrm{~V}^{6.51}$ facing the $\mathrm{R}_{1}$ position is substituted by a leucine residue in the CB1 receptor (Figure 3d), which hamper a proper accommodation of the longer and bulkier $n$ butyl group. Moreover, the L(CB2) ${ }^{3.29} \mathrm{I}(\mathrm{CB} 1)$, and $\mathrm{I} 267(\mathrm{CB} 2) / \mathrm{L} 182$ (CB1) on ECL2, together with the $\mathrm{V}(\mathrm{CB} 2)^{6.51} \mathrm{~L}(\mathrm{CB} 1)$ substitution, further narrow the CB1 receptor binding pocket making it more suitable for smaller substituents with respect to the CB2 receptor binding cleft (Figure 3d).

As regards the substituent on the carboxamide moiety $\left(\mathrm{R}_{2}\right)$, it has not significant effects on the 3methyl-substituted biphenylic derivatives (1-9), while it gains importance in the 3-n-butyl-subsituted series (10-12). In line with the results of Table 1, the cycloheptyl group (10), perfectly fills the hydrophobic pocket defined by $\mathrm{F}^{2.61}$, F97 on ECL1, and $\mathrm{M}^{7.40}$ (see Figure S2 in Supplementary Information). Moreover, the proposed binding modes of $\mathbf{1 0}$, would be also in agreement with the 
observation that, the trans-isomer (11) has an higher $K_{i}$ with respect to cis-isomer $\mathbf{1 2}$, as the trans substitution is less tolerated due to the close proximity of $\mathrm{F}^{2.61}$ side chain (Figure 4).

Finally, the proposed binding mode is in line with the positive effect of electron withdrawing substituent such as the fluorine (4 vs 7, 6 vs 9) or methoxyl group (10-12) as both would increase the T-shaped interaction with $\mathrm{W}^{5.43}$ residue.

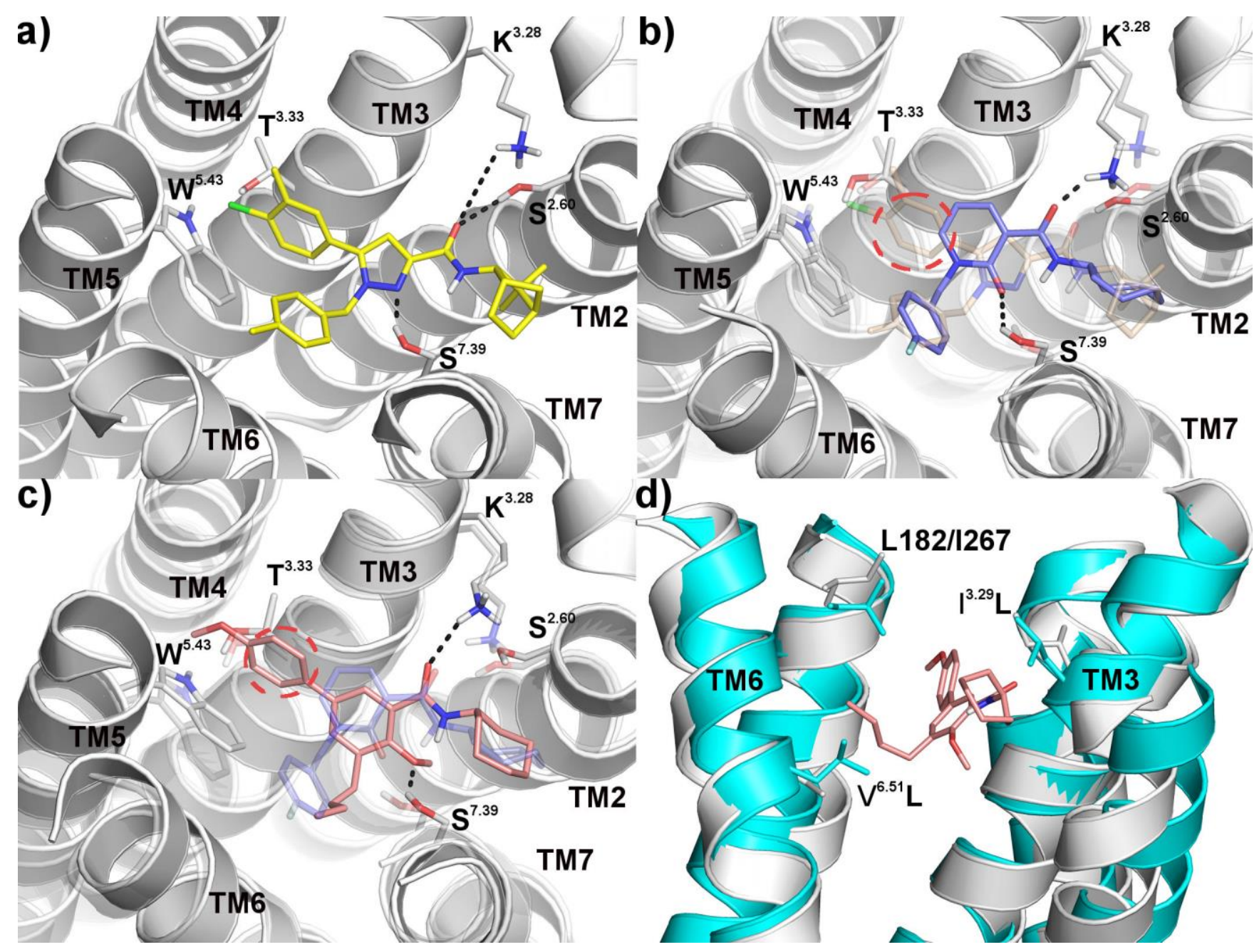

Figure 3. a. Binding mode of SR144528 (yellow sticks) into the CB2 homology model. The CB2 residues interacting with SR144528 are highlighted as yellowwhite sticks. Residues are labeled with Ballesteros-Weinstein numbering; b. Superposition between the binding mode of SR144528 (yellow and transparent sticks) and that of $N$-cycloheptyl-1-[(4-fluorophenyl)methyl]-2-oxo-1,2- 
dihydropyridine-3-carboxamide (blue sticks), CB2 residues interacting with SR144528 are in transparent. The region responsible for the inverse agonist/antagonist behavior is highlighted with a red dashed circle; c. Superposition between the binding mode of the $N$-cycloheptyl-1-[(4fluorophenyl)methyl]-2-oxo-1,2-dihydropyridine-3-carboxamide (blue and transparent sticks) and that of 10 (pink sticks). The region responsible for the inverse agonist/antagonist behavior is highlighted with a red dashed circle; d. Superposition of the CB1 (cyan) and CB2 (white) homology models. Amino acids mutations between the two receptors are highlighted.

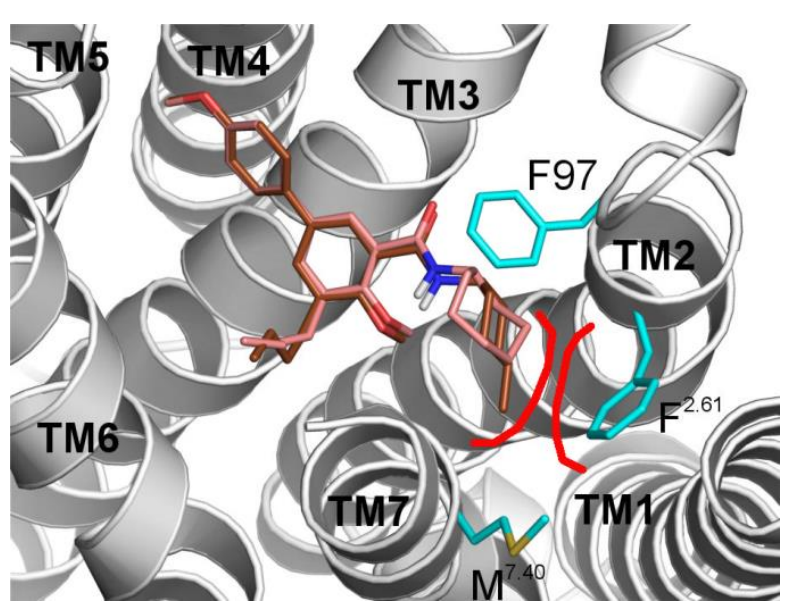

Figure 4. Superposition between the binding mode of $\mathbf{1 0}$ (pink sticks) and that of $\mathbf{1 2}$ (brown sticks). The residues shaping the hydrophobic cleft, responsible for the configurational preference showed by CB2 receptor for the trans- and cis-isomers (11 and $\mathbf{1 2}$ respectively), are represented as cyan sticks. The region of steric hindrance, when the trans-isomer is docked, is highlighted with red lines. 


\section{Conclusion}

In this work we have described the synthesis and biological activity of a series of biphenylic carboxamides as a new class of CB2 receptor selective ligands, some of them showing affinity levels in the $\mathrm{nM}$ range. The most potent and selective derivative of the series (compound 10) showed an interesting pharmacological profile of $\mathrm{CB} 2$ receptor neutral antagonist. In fact, in functional assays compound $\mathbf{1 0}$ proved to be a silent ligand at the CB2 receptor when tested alone, and it was able to dose-dependently antagonize the responses of the agonist HU-210 and of the inverse CB2 receptor agonist SR144528. Since only very few compounds with such characteristics have been reported in the literature, compound $\mathbf{1 0}$ could be considered as the first member of a new series of biphenylic derivatives potentially useful as a pharmacological "tool" to study more in detail the role of CB2 receptor in physiopathological conditions.

Docking studies highlighted that the carbonyl oxygen of the carboxamide moiety and the methoxyl group in position 2 of $\mathbf{1 0}$ form $\mathrm{H}$-bonds with a $\mathrm{K}^{3.28}$ and a $\mathrm{S}^{7.39}$ residues, respectively, in the $\mathrm{CB} 2$ receptor binding cavity. Besides, the $p$-methoxyphenyl group forms a T-shaped interaction with $\mathrm{W}^{5.43}$, fitting well in the TM3-5 cleft. The more hydrophobic interactions by $n$-butyl group with the TM6 hydrophobic residues $\left(\mathrm{V}^{6.51}, \mathrm{~L}^{6.54}, \mathrm{M}^{6.55}\right)$ can explain the increased $\mathrm{CB} 2$ receptor affinity of the 3- $n$ butyl-substituted compounds (10-12) with respect to the 3-methyl-substituted ones (4-9).

Future developments will be directed to the deepening of the structure-activity relationships of this new biphenylic derivatives. For this purpose, we will study the influence on the CB2 receptor activity due to the introduction of other substituents in the carboxamide moiety $\left(\mathrm{R}_{2}\right)$ and/or in the peripheral aromatic ring $\left(\mathrm{R}_{3}\right)$, maintaining the $n$-butyl at position $3\left(\mathrm{R}_{1}\right)$ of the central aromatic ring; or replacing the $n$ butyl at $\mathrm{R}_{1}$ with substituents characterized by different steric and/or electronic properties, such as benzyl, $p$-fluorobenzyl and morpholinoethyl (as in the previously reported 1,2-dihydro-2-oxo-pyridine3-carboxamides series [32]). 


\section{Experimental section}

\subsection{Chemistry}

Commercially available reagents were purchased from Sigma Aldrich or Alfa Aesar, and used without purification. ${ }^{1} \mathrm{H}-\mathrm{NMR}$ spectra were recorded on a Varian Gemini 200 spectrometer (operating at 200 $\mathrm{MHz}$ ) or on a Bruker AVANCE III ${ }^{\mathrm{TM}} 400$ spectrometer (operating at $400 \mathrm{MHz}$ ). ${ }^{13} \mathrm{C}-\mathrm{NMR}$ spectra of

final products were recorded on a Bruker AVANCE III ${ }^{\mathrm{TM}} 400$ spectrometer (operating at $400 \mathrm{MHz}$ ). Chemical shift $(\delta)$ are reported in parts per million related to the residual solvent signal, while coupling constants $(J)$ are expressed in Hertz $(\mathrm{Hz})$. Electron impact $(\mathrm{EI}, 100 \mathrm{eV})$ mass spectra were acquired with a Thermo Quest Finnigan (TRACE GCQ plus) mass spectrometer. All of the final products undergoing biological testing were $>96 \%$ pure as demonstrated by analysis carried out with a Varian Prostar HPLC system equipped with an PDA Detector at $260 \mathrm{~nm}$ (column Luna C18 (2) $5 \mu$ (150 mm $\times$ $4.6 \mathrm{~mm}$ )), gradient A/B 70/30 to 90/10 in $20 \mathrm{~min}$, A consisting of methanol, B consisting of buffer ammonium acetate $(\mathrm{pH}=4,10 \mathrm{mM})$, flow rate of $0.6 \mathrm{~mL} / \mathrm{min}$, room temperature). Evaporation was carried out under vacuum using a rotating evaporator. Silica gel flash chromatography was performed using silica gel $60 \AA$ (0.040-0.063 mm; MERK). Reactions was monitored by TLC on Merck aluminum silica gel $\left(60 \mathrm{~F}_{254}\right)$ plates that were visualized under a UV lamp $(\lambda=254 \mathrm{~nm})$.

\subsubsection{Methyl 2-hydroxy-3-methylbenzoate (14).}

Commercially available 3-methylsalicylic acid $13(4.6 \mathrm{~g}, 29.85 \mathrm{mmol})$ was dissolved in $50 \mathrm{~mL}$ of dichloromethane. Then tetrabutylammonium bromide ( $0.9 \mathrm{~g}, 2.79 \mathrm{mmol})$ was added, followed by a solution of potassium carbonate $(13.4 \mathrm{~g}, 97.3 \mathrm{mmol})$ in water $(25 \mathrm{~mL})$. Finally, dimethyl sulfate $(6.0$ $\mathrm{mL}, 62.8 \mathrm{mmol}$ ) was added to the mixture until a clear solution was obtained. The resulting solution was stirred at room temperature for $4 \mathrm{~h}$ and diluted with water; saturated ammonium chloride aqueous 
solution was then added and the resulting mixture was extracted with dichloromethane. The combined organic layers were dried over anhydrous $\mathrm{Na}_{2} \mathrm{SO}_{4}$, filtered and concentrated under reduced pressure to afford the crude methyl ester $\mathbf{1 4}$ as an oil, used for the next step without further purification. ${ }^{1} \mathrm{H}-\mathrm{NMR}$ $\left(200 \mathrm{MHz}, \mathrm{CDCl}_{3}\right) \delta(\mathrm{ppm}): 2.26(\mathrm{~s}, 3 \mathrm{H}), 3.94$ (s, 3H), $6.78(\mathrm{t}, 1 \mathrm{H}, J=7.8 \mathrm{~Hz}), 7.31(\mathrm{~d}, 1 \mathrm{H}, J=7.2$ $\mathrm{Hz}), 7.67(\mathrm{~d}, 1 \mathrm{H}, J=8.0 \mathrm{~Hz}), 11.02(\mathrm{~s}, 1 \mathrm{H}) ; \mathrm{MS}: \mathrm{m} / z 166\left(\mathrm{M}^{+}, 100\right)$.

\subsubsection{Methyl 2-hydroxy-5-iodo-3-methylbenzoate (15).}

The crude methyl ester 14 was dissolved in methanol $(80.0 \mathrm{~mL})$. Then sodium iodide $(5.5 \mathrm{~g}, 36.86$ mmol) and sodium hydroxide $(1.5 \mathrm{~g}, 36.86 \mathrm{mmol})$ were added, and the solution was cooled to $0{ }^{\circ} \mathrm{C}$. $62.5 \mathrm{~mL}$ of aqueous sodium hypochlorite $(36.86 \mathrm{mmol}, 4 \%)$ was then added dropwise to the stirred solution. The resulting mixture was left under stirring for $5 \mathrm{~h}$, at $0{ }^{\circ} \mathrm{C}$. The reaction mixture was then allowed to warm to room temperature, then treated with $10 \%$ aqueous sodium thiosulfate $(60.0 \mathrm{~mL})$ and acidified with $1 \mathrm{~N}$ aqueous $\mathrm{HCl}$ to get a $\mathrm{pH}=5-6$. The aqueous layer was extracted with diethyl ether. The collected organic fractions were dried over anhydrous $\mathrm{Na}_{2} \mathrm{SO}_{4}$, filtered and concentrated under reduced pressure to afford crude $\mathbf{1 5}(8.0 \mathrm{~g}, 88 \%$ yield) as a yellow solid, that was used for the following step without further purification. ${ }^{1} \mathrm{H}-\mathrm{NMR}\left(200 \mathrm{MHz}, \mathrm{CDCl}_{3}\right) \delta(\mathrm{ppm}): 2.23$ (s, 3H), 3.94 (s, $3 \mathrm{H}), 7.58(\mathrm{~d}, 1 \mathrm{H}, J=2.2 \mathrm{~Hz}), 7.97$ (d, 1H, $J=2.2 \mathrm{~Hz}), 10.96(\mathrm{~s}, 1 \mathrm{H}) ; \mathrm{MS}: m / z 292\left(\mathrm{M}^{+}, 100\right)$.

\subsubsection{Methyl 5-iodo-2-methoxy-3-methylbenzoate (16).}

Methyl 2-hydroxy-5-iodo-3-methylbenzoate 15 (8.0 g, $27.39 \mathrm{mmol})$ was dissolved in dichloromethane (94 ml). Then, tetrabutylammonium bromide $(893 \mathrm{mg}, 2.77 \mathrm{mmol}$ ) was added, followed by an aqueous solution of sodium hydroxide $(3.2 \mathrm{~g}, 79.7 \mathrm{mmol})$ in water $(47.0 \mathrm{ml})$, and finally by dimethyl sulfate (7.4 g, $53.96 \mathrm{mmol}$ ). The mixture was stirred at room temperature overnight. The reaction was quenched with solid ammonium chloride (5.7 $\mathrm{g}$ ), and the $\mathrm{pH}$ was adjust to 5-6 via addition of $0.6 \mathrm{~N}$ 
hydrochloric acid. The two phases were separated, and the aqueous phase was extracted with dichloromethane. The combined organic layers were dried over anhydrous $\mathrm{Na}_{2} \mathrm{SO}_{4}$, filtered, concentrated, and purified by flash column chromatography on silica gel ( $n$-hexane/AcOEt 9:1) obtaining $7.2 \mathrm{~g}(23.56 \mathrm{mmol})$ of pure 16. Yield: 86\%. ${ }^{1} \mathrm{H}-\mathrm{NMR}\left(200 \mathrm{MHz}, \mathrm{CDCl}_{3}\right) \delta(\mathrm{ppm}): 2.25(\mathrm{~s}$, 3H), $3.79(\mathrm{~s}, 3 \mathrm{H}), 3.89(\mathrm{~s}, 3 \mathrm{H}), 7.64(\mathrm{~d}, 1 \mathrm{H}, J=2.4 \mathrm{~Hz}), 7.92(\mathrm{~d}, 1 \mathrm{H}, J=2.4 \mathrm{~Hz})$; MS: $m / z 306\left(\mathrm{M}^{+}\right.$, 100), $307\left([\mathrm{M}+1]^{+}, 79\right), 275\left(\left[\mathrm{M}-\mathrm{OCH}_{3}\right]^{+}, 62\right)$.

\subsubsection{General procedure for the synthesis of derivatives 17-19 and 28}

Palladium acetate $(22.4 \mathrm{mg}, 0.1 \mathrm{mmol})$ and triphenylphosphine $(131.1 \mathrm{mg}, 0.5 \mathrm{mmol})$, under nitrogen flux, were dissolved in anhydrous toluene $(7.6 \mathrm{ml})$. The system was sealed and stirred at room temperature for 15 minutes to allow the formation of the catalyst tetrakis(triphenylphosphine)palladium(0). Then aryl halide $\mathbf{1 6}$ or $\mathbf{2 6}(3.27 \mathrm{mmol})$, a solution of sodium carbonate $(693.2 \mathrm{mg}, 6.54 \mathrm{mmol})$ in water $(7.0 \mathrm{ml})$ and a solution of the corresponding boronic acid $(5.04 \mathrm{mmol})$ in methanol $(7.0 \mathrm{ml})$ were added. The system was sealed again, and stirred at $85{ }^{\circ} \mathrm{C}$, overnight. After cooling, the reaction mixture was quenched with concentrated ammonia (2.3 ml) and saturated aqueous sodium carbonate solution $(7.5 \mathrm{ml})$, and extracted with ethyl acetate. The organic phases were combined, dried over anhydrous $\mathrm{Na}_{2} \mathrm{SO}_{4}$, filtered, concentrated, and purified.

\subsubsection{Methyl 4-methoxy-5-methylbiphenyl-3-carboxylate (17).}

Prepared from 16 using phenylboronic acid. Purified by flash chromatography ( $n$-hexane/AcOEt 9:1). Yield: 53\%. ${ }^{1} \mathrm{H}-\mathrm{NMR}\left(200 \mathrm{MHz}, \mathrm{CDCl}_{3}\right) \delta(\mathrm{ppm}): 2.39(\mathrm{~s}, 3 \mathrm{H}), 3.87(\mathrm{~s}, 3 \mathrm{H}), 3.94(\mathrm{~s}, 3 \mathrm{H})$, 7.34-7.59 $(\mathrm{m}, 6 \mathrm{H}), 7.87(\mathrm{~d}, 1 \mathrm{H}, J=2.4 \mathrm{~Hz})$; MS: $m / z 256\left(\mathrm{M}^{+}, 100\right), 258\left([\mathrm{M}+2]^{+}, 64\right), 225\left(\left[\mathrm{M}-\mathrm{OCH}_{3}\right]^{+}, 26\right)$.

\subsubsection{Methyl 4,4'-dimethoxy-5-methylbiphenyl-3-carboxylate (18).}


Prepared from 16 using 4-methoxy-phenylboronic acid. Purified by flash chromatography ( $n$ hexane/AcOEt 9:1). Yield: 30\%. ${ }^{1} \mathrm{H}-\mathrm{NMR}\left(200 \mathrm{MHz}, \mathrm{CDCl}_{3}\right) \delta$ (ppm): $2.33(\mathrm{~s}, 3 \mathrm{H}), 3.78(\mathrm{~s}, 3 \mathrm{H}), 3.82$ (s, 3H), $6.91\left(\mathrm{AA}^{\prime} \mathrm{XX} X^{\prime}, 2 \mathrm{H}, J_{A X}=8.6 \mathrm{~Hz}, J_{A A^{\prime} / X X^{\prime}}=3.0 \mathrm{~Hz}\right), 7.45\left(\mathrm{AA}^{\prime} \mathrm{XX} X^{\prime}, 2 \mathrm{H}, J_{A X}=8.6 \mathrm{~Hz}, J_{A A^{\prime} / X X^{\prime}}=\right.$ $3.0 \mathrm{~Hz}), 7.48(\mathrm{~d}, 1 \mathrm{H}, J=2.2 \mathrm{~Hz}), 7.79(\mathrm{~d}, 1 \mathrm{H}, J=2.2 \mathrm{~Hz}) ; \mathrm{MS}: m / z 287\left(\mathrm{M}^{+}, 100\right), 288\left([\mathrm{M}+1]^{+}, 41\right)$, $256\left(\left[\mathrm{M}-\mathrm{OCH}_{3}\right]^{+}, 7\right)$.

\subsubsection{Methyl 4'-fluoro-4-methoxy-5-methylbiphenyl-3-carboxylate (19).}

Prepared from 16 using 4-fluoro-phenylboronic acid. Purified by flash chromatography ( $n$ hexane/AcOEt 9:1). Yield: 52\%. ${ }^{1} \mathrm{H}-\mathrm{NMR}\left(200 \mathrm{MHz}, \mathrm{CDCl}_{3}\right) \delta$ (ppm): $2.38(\mathrm{~s}, 3 \mathrm{H}), 3.86(\mathrm{~s}, 3 \mathrm{H}), 3.94$ (s, 3H), 7.05-7.17 (m, 2H), 7.46-7.55 (m, 3H), $7.80(\mathrm{~d}, 1 \mathrm{H}, J=2.4 \mathrm{~Hz}) ; \mathrm{MS}: \mathrm{m} / z 274\left(\mathrm{M}^{+} 100\right), 275$ $\left([\mathrm{M}+1]^{+}, 56\right), 243\left(\left[\mathrm{M}-\mathrm{OCH}_{3}\right]^{+}, 13\right)$.

\subsubsection{Methyl 5-n-butyl-4,4'-dimethoxybiphenyl-3-carboxylate (28).}

Prepared from 26 using 4-methoxy-phenylboronic acid. Purified by flash chromatography ( $n$ hexane/AcOEt 9:1). Yield: 55\%. ${ }^{1} \mathrm{H}-\mathrm{NMR}\left(200 \mathrm{MHz}, \mathrm{CDCl}_{3}\right) \delta(\mathrm{ppm}): 0.95$ (t, 3H, $\left.J=7.0 \mathrm{~Hz}\right), 1.26-$ $1.69(\mathrm{~m}, 4 \mathrm{H}), 2.67-2.75(\mathrm{~m}, 2 \mathrm{H}), 3.84(\mathrm{~s}, 3 \mathrm{H}), 3.86(\mathrm{~s}, 3 \mathrm{H}), 3.94(\mathrm{~s}, 3 \mathrm{H}), 6.96\left(\mathrm{AA}^{\prime} \mathrm{XX} X^{\prime}, 2 \mathrm{H}, J_{A X}=8.9\right.$ $\left.\mathrm{Hz}, J_{A A^{\prime} / X X^{\prime}}=2.6 \mathrm{~Hz}\right), 7.46-7.53(\mathrm{~m}, 3 \mathrm{H}), 7.82(\mathrm{~d}, 1 \mathrm{H}, J=2.4 \mathrm{~Hz}) ; \mathrm{MS}: m / z 328\left(\mathrm{M}^{+}, 100\right), 329$ $\left([\mathrm{M}+1]^{+}, 32\right), 282\left(\left[\mathrm{M}-\mathrm{OCH}_{3}-\mathrm{CH}_{3}\right]^{+}, 12\right)$.

\subsubsection{General procedure for the synthesis of derivatives 20-22 and 29.}

The suitable ester 17-19 $(1.74 \mathrm{mmol})$ was dissolved in methanol $(23.0 \mathrm{ml})$ followed by addition of solid potassium hydroxide $(1.0 \mathrm{~g}, 18.1 \mathrm{mmol})$. The resulting suspension was stirred until completed dissolution of the solids. Then, the mixture was heated at reflux, at $75^{\circ} \mathrm{C}$, for $19 \mathrm{~h}$. The reaction was allowed to cool to room temperature, and methanol was removed in vacuo to afford a yellow oil. The 
oil was partitioned between water and ethyl acetate, therefore the two phases were separated. The aqueous layer was acidified to $\mathrm{pH}=2$, with $0.6 \mathrm{~N}$ aqueous hydrochloric acid solution, to obtain a white precipitate. The precipitate was repeatedly extracted with AcOEt, and the combined organic phases were dried over anhydrous $\mathrm{Na}_{2} \mathrm{SO}_{4}$, filtered and evaporated in vacuo to afford the desired acid derivative, that was used in the next step without further purification.

\subsubsection{4-Methoxy-5-methylbiphenyl-3-carboxylic acid (20).}

Prepared from ester 17. Yield: 69\%. ${ }^{1} \mathrm{H}-\mathrm{NMR}\left(200 \mathrm{MHz}, \mathrm{CDCl}_{3}\right) \delta(\mathrm{ppm}): 2.45$ (s, 3H), 3.97 (s, 3H), 7.40-7.67 (m, 6H), $8.22(\mathrm{~d}, 1 \mathrm{H}, J=2.4 \mathrm{~Hz}) ; \mathrm{MS}: \mathrm{m} / z 242\left(\mathrm{M}^{+}, 64\right), 227\left(\left[\mathrm{M}-\mathrm{CH}_{3}\right]^{+}, 22\right), 225([\mathrm{M}-$ $\left.\mathrm{OH}]^{+}, 19\right)$.

\subsubsection{4,4'-Dimethoxy-5-methylbiphenyl-3-carboxylic acid (21).}

Prepared from ester 18. Yield: 76\%. ${ }^{1} \mathrm{H}-\mathrm{NMR}\left(200 \mathrm{MHz}, \mathrm{CDCl}_{3}\right) \delta(\mathrm{ppm}): 2.43(\mathrm{~s}, 3 \mathrm{H}), 3.85(\mathrm{~s}, 3 \mathrm{H})$, $3.96(\mathrm{~s}, 3 \mathrm{H}), 6.97\left(\mathrm{AA}^{\prime} \mathrm{XX}^{\prime}, 2 \mathrm{H}, J_{\mathrm{AX}}=8.8 \mathrm{~Hz}, J_{\mathrm{AA}^{\prime} / \mathrm{XX}}^{\prime}=2.6 \mathrm{~Hz}\right), 7.52\left(\mathrm{AA}^{\prime} \mathrm{XX}^{\prime}, 2 \mathrm{H}, J_{\mathrm{AX}}=8.8 \mathrm{~Hz}\right.$, $\left.J_{\mathrm{AA}^{\prime} / \mathrm{XX}}=2.6 \mathrm{~Hz}\right), 7.61(\mathrm{~d}, 1 \mathrm{H}, J=2.6 \mathrm{~Hz}), 8.17(\mathrm{~d}, 1 \mathrm{H}, J=2.6 \mathrm{~Hz}) ; \mathrm{MS}: m / z 272\left(\mathrm{M}^{+}, 88\right), 257([\mathrm{M}-$ $\left.\left.\mathrm{CH}_{3}\right]^{+}, 40\right), 255\left([\mathrm{M}-\mathrm{OH}]^{+}, 24\right)$.

\subsubsection{4'-Fluoro-4-methoxy-5-methylbiphenyl-3-carboxylic acid (22).}

Prepared from ester 19. Yield: 75\%. ${ }^{1} \mathrm{H}-\mathrm{NMR}\left(200 \mathrm{MHz}, \mathrm{CDCl}_{3}\right) \delta(\mathrm{ppm}): 2.44(\mathrm{~s}, 3 \mathrm{H}), 3.97(\mathrm{~s}, 3 \mathrm{H})$, 7.09-7.18 (m, 2H), 7.50-7.61 (m, 3H), $8.15(\mathrm{~d}, 1 \mathrm{H}, J=2.4 \mathrm{~Hz})$; MS: $m / z 260\left(\mathrm{M}^{+}, 100\right), 261\left([\mathrm{M}+1]^{+}\right.$, 29), $243\left([\mathrm{M}-\mathrm{OH}]^{+}, 45\right)$.

\subsubsection{5-n-Butyl-4,4'-dimethoxybiphenyl-3-carboxylic acid (29).}


Prepared from ester 28. Yield: 28\%. ${ }^{1} \mathrm{H}-\mathrm{NMR}\left(200 \mathrm{MHz}, \mathrm{CDCl}_{3}\right) \delta(\mathrm{ppm}): 0.97(\mathrm{t}, 3 \mathrm{H}, J=7.1 \mathrm{~Hz})$, 1.76-1.34 (m, 4H), 2.70-2.77 (m, 2H), $3.95(\mathrm{~s}, 3 \mathrm{H}), 3.85(\mathrm{~s}, 3 \mathrm{H}), 6.98\left(\mathrm{AA}^{\prime} \mathrm{XX}^{\prime}, 2 \mathrm{H}, J_{A X}=8.8 \mathrm{~Hz}\right.$, $\left.J_{A A^{\prime} / X X^{\prime}}=3.0 \mathrm{~Hz}\right), 7.52\left(\mathrm{AA}^{\prime} \mathrm{XX}^{\prime}, 2 \mathrm{H}, J_{A X}=8.8 \mathrm{~Hz}, J_{A A^{\prime} / X X^{\prime}}=3.0 \mathrm{~Hz}\right), 7.62(\mathrm{~d}, 1 \mathrm{H}, J=2.6 \mathrm{~Hz}), 8.16(\mathrm{~d}$, 1H, $J=2.6 \mathrm{~Hz})$; MS: $m / z 314\left(\mathrm{M}^{+}, 100\right), 315\left([\mathrm{M}+1]^{+}, 18\right), 257\left([\mathrm{M}-n-\mathrm{Bu}]^{+}, 28\right)$.

\subsubsection{General procedure for the synthesis of carboxamides 1-12.}

The suitable acid 20-22 or $\mathbf{2 9}$ was suspended in thionyl chloride $(\sim 10$ eq) and heated at reflux for 30 minutes. Excess of thionyl chloride was removed by evaporation under nitrogen flux and the obtained acid chloride was treated with a solution of the proper amine $(2.3 \mathrm{eq})$ in dichloromethane. The resulting mixture was stirred at room temperature overnight, and then washed with $0.6 \mathrm{~N}$ aqueous hydrochloric acid solution and saturated aqueous sodium bicarbonate solution. The organic layer was dried over anhydrous $\mathrm{Na}_{2} \mathrm{SO}_{4}$, filtered, concentrated, and purified.

\subsubsection{N-Cycloheptyl-4,4'-dimethoxy-5-methylbiphenyl-3-carboxamide (1).}

Prepared from acid derivative 21 using cycloheptylamine. Purified by flash column chromatography (n-hexane/AcOEt 8:2). Yield: 20\%. ${ }^{1} \mathrm{H}-\mathrm{NMR}\left(200 \mathrm{MHz}, \mathrm{CDCl}_{3}\right) \delta(\mathrm{ppm}): 1.56-2.04(\mathrm{~m}, 12 \mathrm{H}), 2.37(\mathrm{~s}$, $3 \mathrm{H}), 3.78(\mathrm{~s}, 3 \mathrm{H}), 3.84(\mathrm{~s}, 3 \mathrm{H}), 4.15-4.32(\mathrm{~m}, 1 \mathrm{H}), 6.95\left(\mathrm{AA}^{\prime} \mathrm{XX}^{\prime}, 2 \mathrm{H}, J_{A X}=8.8 \mathrm{~Hz}, J_{A A^{\prime} / X X^{\prime}}=2.3 \mathrm{~Hz}\right)$, $7.46(\mathrm{~d}, 1 \mathrm{H}, J=2.4 \mathrm{~Hz}), 7.53\left(\mathrm{AA}^{\prime} \mathrm{XX} X^{\prime}, 2 \mathrm{H}, J_{A X}=8.8 \mathrm{~Hz}, J_{A A^{\prime} / X X^{\prime}}=2.3 \mathrm{~Hz}\right), 7.79(\mathrm{br}, 1 \mathrm{H}), 8.07(\mathrm{~d}, 1 \mathrm{H}$, $J=2.4 \mathrm{~Hz}) ;{ }^{13} \mathrm{C}-\mathrm{NMR}\left(400 \mathrm{MHz}, \mathrm{CDCl}_{3}\right) \delta(\mathrm{ppm}): 16.21,24.27,28.29,35.23,50.41,55.45,61.40$, $114.30,127.32,127.52,128.13,131.85,132.26,132.62,137.22,155.38,159.30,164.44 ;$ MS: $m / z 367$ $\left(\mathrm{M}^{+}, 15\right), 255\left(\mathrm{M}^{+}-\mathrm{NHC}_{7} \mathrm{H}_{13}, 100\right)$.

5.1.6.2. 4,4'-Dimethoxy-N-(trans-4-methylcycloesyl)-5-methylbiphenyl-3-carboxamide (2) and 4,4'Dimethoxy-N-(cis-4-methylcycloesyl)-5-methylbiphenyl-3-carboxamide (3). 
Prepared from acid derivative 21 using 4-methylcyclohexylamine (cis/trans mixture). Purification by flash column chromatography ( $n$-hexane/AcOEt 8:2) allowed the separation of trans- (2) and cis- (3) isomers. 2 (yield 12\%): ${ }^{1} \mathrm{H}-\mathrm{NMR}\left(200 \mathrm{MHz}, \mathrm{CDCl}_{3}\right) \delta(\mathrm{ppm}): 0.92(\mathrm{~d}, 3 \mathrm{H}, J=6.4), 1.09-2.18(\mathrm{~m}, 9 \mathrm{H})$, $2.36(\mathrm{~s}, 3 \mathrm{H}), 3.77(\mathrm{~s}, 3 \mathrm{H}), 3.84(\mathrm{~s}, 3 \mathrm{H}), 3.90-4.05(\mathrm{~m}, 1 \mathrm{H}), 6.96\left(\mathrm{AA}^{\prime} \mathrm{XX} X^{\prime}, 2 \mathrm{H}, J_{A X}=8.8 \mathrm{~Hz}, J_{A A^{\prime} / X X^{\prime}}=\right.$ $2.8 \mathrm{~Hz}), 7.46(\mathrm{~d}, 1 \mathrm{H}, J=2.6 \mathrm{~Hz}), 7.52\left(\mathrm{AA}^{\prime} \mathrm{XX}^{\prime}, 2 \mathrm{H}, J_{A X}=8.8 \mathrm{~Hz}, J_{A A^{\prime} / X X^{\prime}}=2.8 \mathrm{~Hz}\right), 7.63(\mathrm{br}, 1 \mathrm{H})$, $8.06(\mathrm{~d}, 1 \mathrm{H}, J=2.6 \mathrm{~Hz}) ;{ }^{13} \mathrm{C}-\mathrm{NMR}\left(400 \mathrm{MHz}, \mathrm{CDCl}_{3}\right) \delta(\mathrm{ppm}): 16.24 ; 22.37,33.35,34.03,48.57$, $55.49,61.38,114.33,125.35,127.55,128.18,131.98,132.31,132.68,137.26,155.37,159.29,164.87$; MS: $m / z 367\left(\mathrm{M}^{+}, 98\right), 255\left(\mathrm{M}^{+}-\mathrm{NHC}_{7} \mathrm{H}_{13}, 28\right) ; 3$ (yield 31\%): ${ }^{1} \mathrm{H}-\mathrm{NMR}\left(200 \mathrm{MHz}, \mathrm{CDCl}_{3}\right) \delta(\mathrm{ppm})$ : $0.96(\mathrm{~d}, 3 \mathrm{H}, J=6.4), 1.11-2.04(\mathrm{~m}, 9 \mathrm{H}), 2.39(\mathrm{~s}, 3 \mathrm{H}), 3.81(\mathrm{~s}, 3 \mathrm{H}), 3.84(\mathrm{~s}, 3 \mathrm{H}), 4.25-4.39(\mathrm{~m}, 1 \mathrm{H})$, $6.95\left(\mathrm{AA}^{\prime} \mathrm{XX} X^{\prime}, 2 \mathrm{H}, J_{A X}=8.8 \mathrm{~Hz}, J_{A A^{\prime} / X X^{\prime}}=2.6 \mathrm{~Hz}\right), 7.48(\mathrm{~d}, 1 \mathrm{H}, J=2.7 \mathrm{~Hz}), 7.53\left(\mathrm{AA}^{\prime} \mathrm{XX}^{\prime}, 2 \mathrm{H}, J_{A X}=\right.$ $\left.8.8 \mathrm{~Hz}, J_{A A^{\prime} / X X^{\prime}}=2.6 \mathrm{~Hz}\right), 8.08(\mathrm{br}, 1 \mathrm{H}), 8.11(\mathrm{~d}, 1 \mathrm{H}, J=2.7 \mathrm{~Hz}) ;{ }^{13} \mathrm{C}-\mathrm{NMR}\left(400 \mathrm{MHz}, \mathrm{CDCl}_{3}\right) \delta(\mathrm{ppm}):$ $16.31,22.85,29.92,30.38,45.24,55.49,61.60,114.31,127.16,127.61,128.18,131.88,132.44$, 132.64, 137.27, 155.49, 159.31, 164.72; MS: $m / z 367\left(\mathrm{M}^{+}, 7\right), 255\left(\mathrm{M}^{+}-\mathrm{NHC}_{7} \mathrm{H}_{13}, 5\right)$.

\subsubsection{N-Cycloheptyl-4-methoxy-5-methylbiphenyl-3-carboxamide (4).}

Prepared from acid derivative $\mathbf{2 0}$ using cycloheptylamine. Purified by flash column chromatography (n-hexane/AcOEt 9:1). Yield: 60\%. ${ }^{1} \mathrm{H}-\mathrm{NMR}\left(200 \mathrm{MHz}, \mathrm{CDCl}_{3}\right) \delta(\mathrm{ppm}): 1.17-2.05(\mathrm{~m}, 12 \mathrm{H}) ; 2.38(\mathrm{~s}$, 3H), $3.79(\mathrm{~s}, 3 \mathrm{H}), 4.17-4.33(\mathrm{~m}, 1 \mathrm{H}), 7.28-7.62(\mathrm{~m}, 6 \mathrm{H}), 7.78(\mathrm{br}, 1 \mathrm{H}), 8.12(\mathrm{~d}, 1 \mathrm{H}, J=2.4 \mathrm{~Hz})$; ${ }^{13} \mathrm{C}-$ NMR (400 MHz, $\left.\mathrm{CDCl}_{3}\right) \delta(\mathrm{ppm}): 16.15,24.19,28.22,35.15,50.34,61.33,127.02,127.34,127.36$, $127.94,128.78,131.89,132.63,137.50,139.99,155.78,164.28 ; \mathrm{MS}: m / z 337\left(\mathrm{M}^{+}, 10\right), 225\left(\mathrm{M}^{+}-\right.$ $\left.\mathrm{NHC}_{7} \mathrm{H}_{13}, 71\right)$.

5.1.6.4. 4-Methoxy-N-(trans-4-methylcyclohexyl)-5-methylbiphenyl-3-carboxamide (5) and 4-MethoxyN-(cis-4-methylcyclohexyl)-5-methylbiphenyl-3-carboxamide (6). 
Prepared from acid derivative 20 using 4-methylcyclohexylamine (cis/trans mixture). Purification by flash column chromatography ( $n$-hexane/AcOEt 8:2) allowed the separation of trans- (5) and cis- (6) isomers. 5 (yield: 13\%): ${ }^{1} \mathrm{H}-\mathrm{NMR}\left(200 \mathrm{MHz}, \mathrm{CDCl}_{3}\right) \delta(\mathrm{ppm}): 0.92(\mathrm{~d}, 3 \mathrm{H}, J=6.2 \mathrm{~Hz}), 1.03-2.12(\mathrm{~m}$, 9H), $2.38(\mathrm{~s}, 3 \mathrm{H}), 3.78(\mathrm{~s}, 3 \mathrm{H}), 3.90-4.01(\mathrm{~m}, 1 \mathrm{H}), 7.32-7.46(\mathrm{~m}, 3 \mathrm{H}), 7.51(\mathrm{~d}, 1 \mathrm{H}, J=2.4 \mathrm{~Hz}), 7.57-$ $7.61(\mathrm{~m}, 2 \mathrm{H}), 8.11(\mathrm{~d}, 1 \mathrm{H}, J=2.6 \mathrm{~Hz}) ;{ }^{13} \mathrm{C}-\mathrm{NMR}\left(400 \mathrm{MHz}, \mathrm{CDCl}_{3}\right) \delta(\mathrm{ppm}): 16.22,22.35,32.16$, $33.32,34.00,48.57,61.37,127.13,127.43,127.45,128.03,128.86,131.97,132.73,137.62,140.09$, 155.82, 164.78; MS: m/z $337\left(\mathrm{M}^{+}, 16\right), 225\left(\mathrm{M}^{+}-\mathrm{NHC}_{7} \mathrm{H}_{13}, 61\right) ; 6$ (yield 7\%): ${ }^{1} \mathrm{H}-\mathrm{NMR}(200 \mathrm{MHz}$, $\left.\mathrm{CDCl}_{3}\right) \delta(\mathrm{ppm}): 0.96(\mathrm{~d}, 3 \mathrm{H}, J=6.4 \mathrm{~Hz}), 1.11-1.89(\mathrm{~m}, 9 \mathrm{H}), 2.40(\mathrm{~s}, 3 \mathrm{H}), 3.83(\mathrm{~s}, 3 \mathrm{H}), 4.25-4.39(\mathrm{~m}$, 1H), 7.28-7.62 (m, 5H), $7.53(\mathrm{~d}, 1 \mathrm{H}, J=2.6 \mathrm{~Hz}), 8.09(\mathrm{br}, 1 \mathrm{H}), 8.16(\mathrm{~d}, 1 \mathrm{H}, J=2.6 \mathrm{~Hz}) ;{ }^{13} \mathrm{C}-\mathrm{NMR}(400$ $\left.\mathrm{MHz}_{,} \mathrm{CDCl}_{3}\right) \delta(\mathrm{ppm}): 16.31,21.90,29.91,30.37,31.18,45.26,61.59,127.16,127.25,127.48,128.12$ 128.88, 131.99, 132.89, 137.66, 140.09, 155.96, 164.66; MS: $m / z 337\left(\mathrm{M}^{+}, 38\right), 225\left(\mathrm{M}^{+}-\mathrm{NHC}_{7} \mathrm{H}_{13}\right.$, 67).

\subsubsection{N-Cycloheptyl-4'-fluoro-4-methoxy-5-methylbiphenyl-3-carboxamide (7).}

Prepared from acid derivative 22 using cycloheptylamine. Purified by flash column chromatography (n-hexane/AcOEt 8:2). Yield: 42\%. ${ }^{1} \mathrm{H}-\mathrm{NMR}\left(200 \mathrm{MHz}, \mathrm{CDCl}_{3}\right) \delta(\mathrm{ppm}): 2.10-1.56(\mathrm{~m}, 12 \mathrm{H}) ; 2.37(\mathrm{~s}$, 3H), $3.78(\mathrm{~s}, 3 \mathrm{H}), 4.17-4.35(\mathrm{~m}, 1 \mathrm{H}), 7.04-7.16(\mathrm{~m}, 2 \mathrm{H}), 7.45-7.57(\mathrm{~m}, 3 \mathrm{H}), 7.79(\mathrm{br}, 1 \mathrm{H}), 8.06(\mathrm{~d}, 1 \mathrm{H}$, $J=2.4 \mathrm{~Hz}) ;{ }^{13} \mathrm{C}-\mathrm{NMR}\left(400 \mathrm{MHz}, \mathrm{CDCl}_{3}\right) \delta(\mathrm{ppm}): 16.19,24.24,28.27,35.20,50.42,61.41,115.71(\mathrm{~d}$, $J=84 \mathrm{~Hz}), 127.43,127.89,128.66(\mathrm{~d}, J=32 \mathrm{~Hz}), 132.08,132.54,136.19,136.61,155.82,161.35$, 164.23, MS: $m / z 355\left(\mathrm{M}^{+}, 2\right), 243\left(\mathrm{M}^{+}-\mathrm{NHC}_{7} \mathrm{H}_{13}, 20\right)$.

5.1.6.6. 4'-Fluoro-N-(trans-4-methylcyclohexyl)-4-methoxy-5-methylbiphenyl-3-carboxamide (8) and 4'-Fluoro-N-(cis-4-methylcyclohexyl)-4-methoxy-5-methylbiphenyl-3-carboxamide (9). 
Prepared from acid derivative 22 using 4-methylcyclohexylamine (cis/trans mixture). Purification by flash column chromatography ( $n$-hexane/AcOEt 8:2) allowed the separation of trans- (8) and cis- (9) isomers. 8 (yield: $8 \%$ ): ${ }^{1} \mathrm{H}-\mathrm{NMR}\left(200 \mathrm{MHz} \mathrm{CDCl}_{3}\right) \delta(\mathrm{ppm}): 0.92(\mathrm{~d}, 3 \mathrm{H}, J=6.0 \mathrm{~Hz}), 1.09-2.12(\mathrm{~m}$, 9H), 2.37 (s, 3H), $3.93(\mathrm{~s}, 3 \mathrm{H}), 4.20-4.40(\mathrm{~m}, 1 \mathrm{H}), 7.05-7.14(\mathrm{~m}, 2 \mathrm{H}), 7.44-7.63(\mathrm{~m}, 3 \mathrm{H}), 7.88(\mathrm{br}, 1 \mathrm{H})$, $8.04(\mathrm{~d}, 1 \mathrm{H}, J=2.4 \mathrm{~Hz}) ;{ }^{13} \mathrm{C}-\mathrm{NMR}\left(400 \mathrm{MHz}, \mathrm{CDCl}_{3}\right) \delta(\mathrm{ppm}): 16.23,22.36,30.34,32.18,34.01$, 48.60, 61.40, $115.75(\mathrm{~d}, J=84 \mathrm{~Hz}), 127.48,127.94,128.72(\mathrm{~d}, J=32 \mathrm{~Hz}), 132.12,132.59,136.26$, 136.68, 155.81, 161.40, 164.68; MS: $m / z 355\left(\mathrm{M}^{+}, 4\right), 243\left(\mathrm{M}^{+}-\mathrm{NHC}_{7} \mathrm{H}_{13}, 12\right)$; 9 (yield 30\%): ${ }^{1} \mathrm{H}-$ NMR $\left(200 \mathrm{MHz}, \mathrm{CDCl}_{3}\right) \delta(\mathrm{ppm}): 0.96(\mathrm{~d}, 3 \mathrm{H}, J=7.0 \mathrm{~Hz}), 1.16-1.86(\mathrm{~m}, 9 \mathrm{H}), 2.40(\mathrm{~s}, 3 \mathrm{H}), 3.82(\mathrm{~s}$, $3 \mathrm{H}), 4.15-4.40(\mathrm{~m}, 1 \mathrm{H}), 7.06-7.15(\mathrm{~m}, 2 \mathrm{H}), 7.46-7.58(\mathrm{~m}, 3 \mathrm{H}), 8.05(\mathrm{br}, 1 \mathrm{H}), 8.10(\mathrm{~d}, 1 \mathrm{H}, J=2.2 \mathrm{~Hz})$; ${ }^{13} \mathrm{C}-\mathrm{NMR}\left(400 \mathrm{MHz}, \mathrm{CDCl}_{3}\right) \delta(\mathrm{ppm}): 16.27,22.33,29.88,30.35,33.99,45.26,61.57,115.72(\mathrm{~d}, J=$ $84 \mathrm{~Hz}), 127.29,127.97,128.69$ (d, $J=32 \mathrm{~Hz}), 132.09,132.69,136.23,136.66,155.92,161.38,163.83$; MS: $m / z 355\left(\mathrm{M}^{+}, 2\right), 243\left(\mathrm{M}^{+}-\mathrm{NHC}_{7} \mathrm{H}_{13}, 14\right)$.

\subsubsection{5-n-Butyl-4,4'-dimethoxy-N-cycloheptylbiphenyl-3-carboxamide (10).}

Prepared from acid derivative $\mathbf{2 9}$ using cycloheptylamine. Purified by flash column chromatography ( $n$-hexane/AcOEt 8:2). Yield: 66\%. ${ }^{1} \mathrm{H}-\mathrm{NMR}\left(400 \mathrm{MHz}, \mathrm{CDCl}_{3}\right) \delta(\mathrm{ppm}): 0.97(\mathrm{t}, 3 \mathrm{H}, J=7.3 \mathrm{~Hz})$, 1.39-1.49 (m, 2H), 1.53-1.71 (m, 12H), 2.01-2.10 (m, 2H), 2.67-2.71 (m, 2H), $3.78(\mathrm{~s}, 3 \mathrm{H}), 3.84(\mathrm{~s}$, $3 \mathrm{H}), 4.20-4.29(\mathrm{~m}, 1 \mathrm{H}), 6.96\left(\mathrm{AA}^{\prime} \mathrm{XX}^{\prime}, 2 \mathrm{H}, J_{A X}=8.7 \mathrm{~Hz}, J_{A A^{\prime} / X X^{\prime}}=2.6 \mathrm{~Hz}\right), 7.47(\mathrm{~d}, 1 \mathrm{H}, J=2.5 \mathrm{~Hz})$, $7.52\left(\mathrm{AA}^{\prime} \mathrm{XX}\right.$ ', 2H, $\left.J_{A X}=8.7 \mathrm{~Hz}, J_{A A^{\prime} / X X^{\prime}}=2.6 \mathrm{~Hz}\right), 7.66(\mathrm{br}, 1 \mathrm{H}), 8.04(\mathrm{~d}, 1 \mathrm{H}, J=2.5 \mathrm{~Hz}) ;{ }^{13} \mathrm{C}-\mathrm{NMR}$ $\left(400 \mathrm{MHz}, \mathrm{CDCl}_{3}\right) \delta(\mathrm{ppm}): 14.09,22.92,24.28,28.27,29.53,33.14,35.23,50.47,55.43,62.29$, $114.27,127.46,127.60,128.14,131.20,132.75,136.65,137.23,155.09,159.27,164.61 ; \mathrm{MS}: \mathrm{m} / z 409$ $\left(\mathrm{M}^{+}, 31\right), 297\left(\mathrm{M}^{+}-\mathrm{NHC}_{7} \mathrm{H}_{13}, 22\right)$. 
5.1.6.8. 5-n-Butyl-4,4'-dimethoxy-N-(trans-4-methylcyclohexyl)biphenyl-3-carboxamide (11) and 5-nButyl-4,4'-dimethoxy-N-(cis-4-methylcyclohexyl)biphenyl-3-carboxamide (12).

Prepared from acid derivative 29 using 4-methylcyclohexylamine (cis/trans mixture). Purification by flash column chromatography ( $n$-hexane/AcOEt 8:2) allowed the separation of trans- (11) and cis- (12) isomers. 11 (yield 38\%): ${ }^{1} \mathrm{H}-\mathrm{NMR}\left(200 \mathrm{MHz}, \mathrm{CDCl}_{3}\right) \delta(\mathrm{ppm}):$ 0.82-1.00 (m, 6H), 1.09-1.79 (m, 13H), 2.64-2.72 (m, 2H), $3.77(\mathrm{~s}, 3 \mathrm{H}), 3.84(\mathrm{~s}, 3 \mathrm{H}), 3.90-4.05(\mathrm{~m}, 1 \mathrm{H}), 6.95\left(\mathrm{AA}^{\prime} \mathrm{XX} X^{\prime}, 2 \mathrm{H}, J_{A X}=8.8 \mathrm{~Hz}\right.$, $\left.J_{A A^{\prime} X X X^{\prime}}=2.5 \mathrm{~Hz}\right), 7.46(\mathrm{~d}, 1 \mathrm{H}, J=2.4 \mathrm{~Hz}), 7.52\left(\mathrm{AA}^{\prime} X X^{\prime}, 2 \mathrm{H}, J_{A X}=8.8 \mathrm{~Hz}, J_{A A^{\prime} / X X^{\prime}}=2.5 \mathrm{~Hz}\right), 8.03(\mathrm{~d}$, $1 \mathrm{H}, J=2.4 \mathrm{~Hz}) ;{ }^{13} \mathrm{C}-\mathrm{NMR}\left(400 \mathrm{MHz}, \mathrm{CDCl}_{3}\right) \delta(\mathrm{ppm}): 14.12,22.37,22.95,29.60,32.19,33.19,33.33$, $34.04,48.59,55.49,62.27,114.32,127.50,127.65,128.20,131.27,132.81,136.70,137.29,155.09$, 159.31, 165.07; MS: $m / z 409\left(\mathrm{M}^{+}, 100\right), 297\left(\mathrm{M}^{+}-\mathrm{NHC}_{7} \mathrm{H}_{13}, 81\right) ; 12$ (yield: 23\%): ${ }^{1} \mathrm{H}-\mathrm{NMR}$ (400 $\left.\mathrm{MHz}, \mathrm{CDCl}_{3}\right) \delta(\mathrm{ppm}): 0.96(\mathrm{~d}, 3 \mathrm{H}, J=6.6 \mathrm{~Hz}), 0.98(\mathrm{t}, 3 \mathrm{H}, J=7.3 \mathrm{~Hz}), 1.41-1.49(\mathrm{~m}, 2 \mathrm{H}), 1.57-1.88$ (m, 11H), 2.69-2.73 (m, 2H), $3.81(\mathrm{~s}, 3 \mathrm{H}), 3.85(\mathrm{~s}, 3 \mathrm{H}), 4.27-4.35(\mathrm{~m}, 1 \mathrm{H}), 6.96\left(\mathrm{AA}^{\prime} \mathrm{XX} X^{\prime}, 2 \mathrm{H}, J_{A X}=\right.$ $\left.8.8 \mathrm{~Hz}, J_{A A^{\prime} X X^{\prime}}=2.3 \mathrm{~Hz}\right), 7.48(\mathrm{~d}, 1 \mathrm{H}, J=2.5 \mathrm{~Hz}), 7.53\left(\mathrm{AA}^{\prime} X X^{\prime}, 2 \mathrm{H}, J_{A X}=8.8 \mathrm{~Hz}, J_{A A^{\prime}}{ }^{\prime} X X^{\prime}=2.3 \mathrm{~Hz}\right)$, 7.95 (br, $1 \mathrm{H}), 8.08(\mathrm{~d}, 1 \mathrm{H}, J=2.5 \mathrm{~Hz}) ;{ }^{13} \mathrm{C}-\mathrm{NMR}\left(400 \mathrm{MHz}, \mathrm{CDCl}_{3}\right) \delta(\mathrm{ppm}): 14.12,21.73,22.98$, $29.49,29.84,30.40,33.13,45.41,55.48,62.48,114.32,127.50,127.54,128.20,131.30,132.82$, 136.69, 137.31, 155.22, 159.32, 164.94; MS: $m / z 409\left(\mathrm{M}^{+}, 100\right), 297\left(\mathrm{M}^{+}-\mathrm{NHC}_{7} \mathrm{H}_{13}, 51\right)$.

\subsubsection{Methyl 3-bromo-2-methoxybenzoate (24).}

Concentrated sulfuric acid $(2.0 \mathrm{ml})$ was slowly added to a solution of the commercially available 3 bromo-2-methoxybenzoic acid $23(2.0 \mathrm{~g}, 8.66 \mathrm{mmol})$ in methanol $(40.0 \mathrm{ml})$, and the mixture was refluxed overnight. Then the mixture was allowed to cool to room temperature and neutralized with saturated aqueous sodium bicarbonate solution. The aqueous layer was extracted several times with ethyl acetate, and the combined organic phases were dried over anhydrous $\mathrm{Na}_{2} \mathrm{SO}_{4}$, filtered and concentrated in vacuo to give pure 24 in $60 \%$ yield. ${ }^{1} \mathrm{H}-\mathrm{NMR}\left(200 \mathrm{MHz}, \mathrm{CDCl}_{3}\right) \delta(\mathrm{ppm}): 3.92(\mathrm{~s}, 6 \mathrm{H})$, 
$7.03(\mathrm{t}, 1 \mathrm{H}, J=7.9 \mathrm{~Hz}), 7.70(\mathrm{dd}, 1 \mathrm{H}, J=6.4 \mathrm{~Hz}, J=1.6 \mathrm{~Hz}), 7.74(\mathrm{dd}, 1 \mathrm{H}, J=6.4 \mathrm{~Hz}, J=1.6 \mathrm{~Hz})$;

MS: $m / z 245\left(\mathrm{M}^{+}, 100\right), 247\left([\mathrm{M}+2]^{+}, 88\right), 214\left(\left[\mathrm{M}-\mathrm{OCH}_{3}\right]^{+}, 72\right), 216\left(\left[\mathrm{M}+2-\mathrm{OCH}_{3}\right]^{+}, 57\right)$.

\subsubsection{Methyl 3-n-butyl-2-methoxybenzoate (25).}

Bis(dibenzylideneacetone)dipalladium(0) (11.5 $\mathrm{mg}, 2 \% \mathrm{~mol})$ and 1,2,3,4,5-pentaphenyl-1-(di-tertbutylphosphino)ferrocene $(29.1 \mathrm{mg}, 1 \% \mathrm{~mol}$ ) were added, under nitrogen flux, to a solution of $\mathbf{2 4}$ (500 $\mathrm{mg}, 2.04 \mathrm{mmol})$ in anhydrous toluene $(5 \mathrm{ml})$, followed by $\mathrm{K}_{3} \mathrm{PO}_{4}(874 \mathrm{mg}, 4.12 \mathrm{mmol})$ and $n$-butylboronic acid $(251.8 \mathrm{mg}, 2.47 \mathrm{mmol})$. The system was sealed, and the reaction mixture was stirred at $100{ }^{\circ} \mathrm{C}$ for 19 hours. After cooling to room temperature, toluene was removed by evaporation in vacuo to afford the crude product that was purified by flash column chromatography on silica gel ( $n$ hexane/AcOEt 9:1) to give pure 25 (400 mg, yield: $88 \%$ ). ${ }^{1} \mathrm{H}-\mathrm{NMR}\left(200 \mathrm{MHz}, \mathrm{CDCl}_{3}\right) \delta$ (ppm): 0.93 (t, 3H, $J=7.3 \mathrm{~Hz}), 1.25-1.66(\mathrm{~m}, 4 \mathrm{H}), 2.62-2.70(\mathrm{~m}, 1 \mathrm{H}), 3.83(\mathrm{~s}, 3 \mathrm{H}), 3.91(\mathrm{~s}, 3 \mathrm{H}), 7.07$ (t, $1 \mathrm{H}, J=7.6$ $\mathrm{Hz}), 7.35(\mathrm{dd}, 1 \mathrm{H}, J=7.5 \mathrm{~Hz}, J=1.8 \mathrm{~Hz}), 7.64(\mathrm{dd}, 1 \mathrm{H}, J=7.5 \mathrm{~Hz}, J=1.8 \mathrm{~Hz}) ; \mathrm{MS}: m / z 222\left(\mathrm{M}^{+}, 40\right)$, $223\left([\mathrm{M}+1]^{+}, 100\right), 191\left(\left[\mathrm{M}-\mathrm{OCH}_{3}\right]^{+}, 21\right)$.

\subsubsection{Methyl 5-bromo-3-n-butyl-2-methoxybenzoate (26) and methyl 5-bromo-3-n-butyl-2-} hydroxybenzoate (27).

Compound 25 (300 mg, $1.35 \mathrm{mmol}$ ) was dissolved in $2.3 \mathrm{ml}$ of chloroform. Then, a solution of bromine $(0.07 \mathrm{ml}, 1.37 \mathrm{mmol})$ in chloroform $(1.4 \mathrm{ml})$ was slowly added at room temperature. The reaction mixture was stirred at room temperature overnight. After washing once with saturated aqueous sodium thiosulfate solution, the organic layer was dried over anhydrous sodium sulfate, filtered and concentrated in vacuo. The crude product was purified by flash column chromatography on silica gel ( $n$-hexane/AcOEt 9:1) to give $140 \mathrm{mg}$ of pure $\mathbf{2 6}$ (yield: 34\%) and $90 \mathrm{mg}$ of pure $\mathbf{2 7 .} 26:{ }^{1} \mathrm{H}-\mathrm{NMR}$ (200 $\left.\mathrm{MHz}, \mathrm{CDCl}_{3}\right) \delta(\mathrm{ppm}): 0.93(\mathrm{t}, 3 \mathrm{H}, J=7.14), 1.25-1.65(\mathrm{~m}, 4 \mathrm{H}), 2.58-2.66(\mathrm{~m}, 2 \mathrm{H}), 3.81(\mathrm{~s}, 3 \mathrm{H}), 3.91$ 
(s, 3H), $7.45(\mathrm{~d}, 1 \mathrm{H}, J=2.6 \mathrm{~Hz}), 7.76(\mathrm{~d}, 1 \mathrm{H}, J=2.6 \mathrm{~Hz})$; MS: $m / z 301\left(\mathrm{M}^{+}, 100\right), 303\left([\mathrm{M}+2]^{+}, 73\right)$, $270\left(\left[\mathrm{M}-\mathrm{OCH}_{3}\right]^{+}, 19\right) ; 27:{ }^{1} \mathrm{H}-\mathrm{NMR}\left(\mathrm{CDCl}_{3}\right) \delta(\mathrm{ppm}): 0.93(\mathrm{t}, 3 \mathrm{H}, J=7.1 \mathrm{~Hz}), 1.24-1.65(\mathrm{~m}, 4 \mathrm{H})$, 2.56-2.69 (m, 2H), 3.95 (s, 3H), 7.40 (d, 1H, $J=2.4 \mathrm{~Hz}), 7.80(\mathrm{~d}, 1 \mathrm{H}, J=2.4 \mathrm{~Hz}), 10.96$ (s, 1H); MS: $m / z 287\left(\mathrm{M}^{+}, 74\right), 289\left([\mathrm{M}+2]^{+}, 47\right), 256\left(\left[\mathrm{M}-\mathrm{OCH}_{3}\right]^{+}, 8\right)$.

5.1.10. Methyl 5-bromo-3-n-butyl-2-methoxybenzoate (26) from methyl 5-bromo-3-n-butyl-2hydroxybenzoate (27).

Methyl 5-bromo-3- $n$-butyl-2-hydroxy-benzoate 27 (790.0 $\mathrm{mg}, 2.75 \mathrm{mmol})$ was dissolved in dichloromethane $(8.9 \mathrm{ml})$. Then, tetrabutylammonium bromide $(90.3 \mathrm{mg}, 0.28 \mathrm{mmol})$ was added, followed by an aqueous solution of sodium hydroxide $(320.1 \mathrm{mg}, 8.00 \mathrm{mmol})$ in water $(4.5 \mathrm{ml})$, and finally by dimethyl sulfate $(683.3 \mathrm{mg}, 5.42 \mathrm{mmol})$. The mixture was stirred at room temperature overnight. The reaction was quenched with solid ammonium chloride $(0.50 \mathrm{~g})$, and the $\mathrm{pH}$ was adjust to 5-6 via addition of $0.6 \mathrm{~N}$ hydrochloric acid. The two phases were separated, and the aqueous phase was extracted with dichloromethane. The combined organic layers were dried over anhydrous $\mathrm{Na}_{2} \mathrm{SO}_{4}$, filtered, concentrated, and purified by flash column chromatography on silica gel ( $n$-hexane/AcOEt 9:1) obtaining $360.0 \mathrm{mg}(1.2 \mathrm{mmol})$ of pure $\mathbf{2 6}$. Yield: $44 \%$.

\section{2. $C B 1$ and $C B 2$ receptor binding assays}

The new compounds were evaluated in CB1 and CB2 receptors binding assays using membranes from HEK-293 cells transfected with cDNAs encoding the human recombinant CB1receptor (Bmax) 2.5 $\mathrm{pmol} / \mathrm{mg}$ protein and human recombinant CB2 receptor (Bmax) $4.7 \mathrm{pmol} / \mathrm{mg}$ protein (PerkineElmer, Italy). These membranes were incubated with $\left.\left[{ }^{3} \mathrm{H}\right] \mathrm{CP} 55,940\right)\left(0.14 \mathrm{nM} / k_{\mathrm{d}}{ }^{1 / 4} 0.18 \mathrm{nM}\right.$ and $0.084 \mathrm{nM} / k_{\mathrm{d}}$ $1 / 40.31 \mathrm{nM}$ for $\mathrm{CB} 1$ and $\mathrm{CB} 2$ receptors, respectively) as the high affinity ligand and displaced with 100 $\mathrm{nM}$ of WIN55212-2 as the heterologous competitor for nonspecific binding ( $K_{\mathrm{i}}$ values 9.2 and $2.1 \mathrm{nM}$, 
respectively, for $\mathrm{CB} 1$ and $\mathrm{CB} 2$ receptor). All compounds were tested following the procedure described by the cell membrane manufacturer. Displacement curves were generated by incubating drugs with $\left[{ }^{3} \mathrm{H}\right] \mathrm{CP} 55,940$ for $90 \mathrm{~min}$ at $30^{\circ} \mathrm{C}$. $K_{\mathrm{i}}$ values were calculated by applying the Cheng-Prusoff equation to the $\mathrm{IC}_{50}$ values (obtained by GraphPad) for the displacement of the bound radioligand by increasing concentrations of the test compound. Data are the mean (SEM of at least $\mathrm{n}=3$ experiments).

\subsection{Functional Activity at $C B 1$ and $C B 2$ receptor in Vitro}

The $\left[{ }^{35} \mathrm{~S}\right] \mathrm{GTP} \gamma \mathrm{S}$ binding experiments were performed according to the reported procedures $[29,40]$. The results were calculated using GraphPad Prism 5.0 (California, USA). The studies were conducted in three independent experiments performed in duplicates. $\mathrm{IC}_{50}$ and $\mathrm{EC}_{50}$ values are presented as mean \pm s.e.m.

\subsection{Computational Protocol}

Homology Modelling. Three-dimensional models of both CB1 and CB2 receptors were generated through the Modeller 9.11 software [49] as previously reported by us [42]. Basically, the $\mathrm{S}_{1} \mathrm{P}_{1} \mathrm{X}$-ray crystal structure (pdb code: $3 \mathrm{~V} 2 \mathrm{Y}$ [50]) was chosen and used as template to generate the 3D structure of both $\mathrm{CB} 1$ and $\mathrm{CB} 2$ receptors. $\mathrm{CB} 1, \mathrm{CB} 2$ and $\mathrm{S} 1 \mathrm{P}_{1}$ sequences were aligned using the ClustalW server [51] (see Figure S1 in Supplementary Information).

Molecular Docking. All the ligands used for the docking studies were built using the fragment builder tool of Maestro9.1. [52]. The compounds were geometrically optimized by means of Macromodel [52], using MMFFs as force field, water as implicit solvent until a convergence value of $0.05 \mathrm{kcal} / \mathrm{mol}^{*} \AA^{2}$. The computational protocol applied consist of the application of 500 steps of the Polak-Ribiére conjugate gradient (PRCG) for structure minimizations. The $\mathrm{CB} 1$ and $\mathrm{CB} 2$ protein structure was prepared through the Protein Preparation Wizard of Maestro9.1 [52]. SR144528 and N-cycloheptyl-1- 
[(4-fluorophenyl)methyl]-2-oxo-1,2-dihydropyridine-3-carboxamide dockings were accomplished through the Glide induced fit docking (IFD) tool available in Maestro9.1. [52]. The grid was centered on the residues shaping the orthosteric binding pocket for which mutagenesis data are available [44-47] $\left(\mathrm{S}^{2.60}, \mathrm{~K}^{3.28}, \mathrm{~W}^{5.43}, \mathrm{~W}^{6.48}\right.$, and $\mathrm{S}^{7.39}$ according to Ballesteros-Weinstein numbering [53]. The flexible region of the protein was fixed until $8 \AA$ around the center of the grid. Each docking run was carried out with the standard precision (SP) method, and the van deer Waals scaling factor of non polar atoms was set to 0.8 . Fifteen docking poses were obtained and among these poses we selected the best pose in accordance with the mutagenesis data [44-47], and structure-activity relationship studies previously reported for this class of CB2 ligands [44-47]. Finally, compounds reported in Table 1 were docked using as reference structure the refined CB2-SR144528 complex. Similarly to the structure of SR144528 all the compounds reported in Table 1 have a third aromatic ring, therefore the CB2SR144528 complex was used for the subsequent docking studies. In this case the grid for the docking studies was centered directly on the SR144528 ligand binding pose, and the SP docking method was used. For each compound, the binding mode with the highest Glide score was selected. The selected docking pose were minimized using OPLSA2005 as force field, the PRCG methods until a gradient of $0.001 \mathrm{kcal} / \mathrm{mol}^{*} \AA^{2}$ applying a stepwise relaxation protocol for which harmonic constraints were progressively reduced for backbone, side chains and ligand atoms.

\section{Acknowledgements}

Authors want to thank Mrs. Tiina Koivunen and Mrs. Helly Rissanen for technical assistance. This work was supported by National Interest Research Projects (PRIN 2010-2011, Grant 20105YY2HL_008) and by the Academy of Finland (grants 127653, 139140, 139620). 


\section{References}

[1] P. Pacher, S. Batkai, G. Kunos, Pharmacol. Rev. 58 (2006) 389-462.

[2] C. Howlett, F. Barth, T. I. Bonner, G. Cabral, P. Casellas, W. A. Devane, C. C. Felder, M. Herkenham, K. Mackie, B. R. Martin, R. Mechoulam, R. G. Pertwee, Pharmacol. Rev. 54 (2002) $161-202$.

[3] R. G. Pertwee, R. A. Ross, Prostaglandins Leukot. Essent. Fatty Acids 66 (2002) 101-121.

[4] R. G. Pertwee, Br. J. Pharmacology 156 (2009) 397-411.

[5] M. D.Van Sickle, M. Duncan, P. J. Kingsley, A. Mouihate, P. Urbani, K. Mackie, N. Stella, A. Makriyannis, D. Piomelli, J. S. Davison, L. J. Marnett, V. Di Marzo, Q. J. Pittman, K. D.

Patel, K. A. Sharkey, Science 310 (2005) 329-32.

[6] P. Pacher, R. Mechoulam, Prog. Lipid Res. 50 (2011) 193-211.

[7] R. G. Pertwee, Phil. Trans. R. Soc. B 367 (2012) 3353-3363.

[8] S. D. Skaper, V. Di Marzo, Phil. Trans. R. Soc. B 367 (2012) 3193-3200.

[9] D. R. Compton, K. C. Rice, B. R. De Costa, R. K. Razdan, L. S. Melvin, M. R. Johnson, B. R. Martin, J. Pharmacol. Exp. Ther. 265 (1993) 218-226.

[10] T. P. Jr. Malan, M. M. Ibrahim, J. Lai, T. W. Vanderah, A. Makriyannis, F. Porreca, Curr. Opin. Pharmacol. 3 (2003) 62-67.

[11] T. Bisogno, V. Di Marzo, CNS Neurol. Disord. Drug Targets 9 (2010) 564-573.

[12] D. Centonze, A. Finazzi-Agro, G. Bernardi, M. Maccarrone, Trends Pharmacol. Sci. 28 (2007) $180-187$.

[13] M. A. Storr, C. M. Keenan, H. Zhang, K. D. Patel, A. Makriyannis, K. A. Sharkey, Inflamm. Bowel. Dis. 15 (2009) 1678-1685. 
[14] M. Rajesh, P. Mukhopadhyay, G. Hasko, J. W. Huffman, K. Mackie, P. Pacher, Br. J. Pharmacol. 153 (2008) 347-357.

[15] I. Bab, O. Ofek, J. Tam, J. Rehnelt, A. Zimmer, J. Neuroendocrinol. 20(Suppl. 1) (2008), 69-74.

[16] O. Ofek, M. Karsak, N. Leclerc, M. Fogel, B. Frenkel, K. Wright, J. Tam, M. Attar-Namdar, V. Kram, E. Shohami, R. Mechoulam, A. Zimmer, I. Bab, Proc. Natl. Acad. Sci. U.S.A. 103 (2006) 696-701.

[17] C. Benito, R. M. Tolon, M. R. Pazos, E. Nunez, A. I. Castillo, J. Romero, Br. J. Pharmacol. 153 (2008) 277-285.

[18] S. Pisanti, P. Picardi, A. D’Alessandro, C. Laezza, M. Bifulco, Trends Pharmacol. Sci. 34 (2013) $273-282$.

[19] P. Anand, G. Whiteside, C. J. Fowler, A. G. Hohmann, Brain Res. Rev. 60 (2009) 255-266.

[20] J. Guindon, A. G. Hohmann, Br. J. Pharmacol. 153 (2008) 319-334.

[21] F. Vincenzi, M. Targa, C. Corciulo, M. A. Tabrizi, S. Merighi, S. Gessi, G. Saponaro, P. G. Baraldi, P. A. Borea, K. Varani, Pain 154 (2013) 864-873.

[22] B. B. Yao, G. C. Hsieh, J. M. Frost, Y. Fan, T. R. Garrison, A. V. Daza, G. K. Grayson, C. Z. Zhu, M. Pai, P. Chandran, A. K. Salyers, E. J. Wensink, P. Honore, J. P. Sullivan, M. J. Dart, M. D. Meyer, Br. J. Pharmacol. 153 (2008) 390-401.

[23] M. G. Cascio, D. Bolognini, R. G. Pertwee, E. Palazzo, F. Corelli, S. Pasquini, V. Di Marzo, S. Maione, Pharmacol. Res. 61 (2010) 349-354.

[24] H. Iwamura, H. Suzuki, Y. Ueda, T. Kaya, T. Inaba, J. Pharmacol. Exp. Ther. 296 (2001) 420425.

[25] I. Bab, O. Ofek, J. Tam, J. Rehnelt, A. Zimmer, J. Neuroendocrinol. 20 (2008) 69-74.

[26] O. Ofek, M. Attar-Namdar, V. Kram, M. Dvir-Ginzberg, R. Mechoulam, A. Zimmer, B. Frenkel, E. Shohami, I. Bab, J. Bone Miner. Res. 26 (2011) 308-316. 
[27] P. Yang, K. Z. Myint, Q. Tong, R. Feng, H. Cao, A. A. Almehizia, M. H. Alqarni, L. Wang, P. Bartlow, Y. Gao, J. Gertsch, J. Teramachi, N. Kurihara, G. D. Roodman, T. Cheng, X. Q. Xie, J. Med. Chem. 55 (2012) 9973-9987.

[28] A. I. Idris, A. Sophocleous, E. L. Bassonga, R. J. van’t Hof, S. H. Ralston, Endocrinology 149 (2008) 5619-5626.

[29] J. R. Savinainen, T. Kokkola, O. M. Salo, A. Poso, T. Järvinen, J. T. Laitinen, Br. J. Pharmacol. 145 (2005) 636-645.

[30] G. G. Muccioli, Chem. Biodivers. 4 (2007) 1805-1827.

[31] R. G. Pertwee, Tocris Bioscience Scientific Reviews Series (2010), www.tocris.com.

[32] V. Lucchesi, T. Parkkari, J. R. Savinainen, A. M. Malfitano, M. Allarà, S. Bertini, F. Castelli, S. Del Carlo, C. Laezza, A. Ligresti, G. Saccomanni, M. Bifulco, V. Di Marzo, M. Macchia, C. Manera, Eur. J. Med. Chem. 74 (2014) 524-553.

[33] B. L. Deng, T. L. Hartman, R. W. Buckheit, Jr., C. Pannecouque, E. De Clercq, P. E. Fanwick, M. Cushman, J. Med. Chem. 48 (2005), 6140-6155.

[34] S. K. Khim, M. Dai, X. Zhang, L. Chen, L. Pettus, K. Thakkar, A. G. Schultz, J. Org. Chem. 69 (2004) 7728-7733.

[35] M. D. Cullen, B. L. Deng, T. L. Hartman, K. M. Watson, R. W. Buckheit Jr., C. Pannecouque, E. De Clercq, M. Cushman, J. Med. Chem. 50 (2007) 4854-4867.

[36] D. Shabashov, J. R. Molina Maldonado, O. Daugulis, J. Org. Chem. 73 (2008) 7818-7821.

[37] C. Chiappe, F. D’Andrea, 2003, Edizioni ETS, Pisa.

[38] N. Kataoka, Q. Shelby, J. P. Stambuli, J. F. Hartwig, J. Org. Chem. 67 (2002) 5553-5566.

[39] N. Gisch, J. Balzarini, C. Meier, J. Med. Chem. 50 (2007) 1658-1667.

[40] J. R. Savinainen, S.M. Saario, R. Niemi, T. Järvinen, J. T. Laitinen, Br J Pharmacol. 140 (2003) $145-1459$. 
[41] D. J. A. Wyllie, P. E. Chen, Br. J. Pharmacol. 150 (2007) 541-551.

[42] A. Bruno, F. Lembo, E. Novellino, M. Stornaiuolo, L. Marinelli, Sci. Rep. 4 (2014).

[43] D. P. Hurst, M. Schmeisser, P. H. Reggio, Chem. Phys. Lipids 169 (2013) 46-56.

[44] D. P. Hurst, A. Grossfield, D. L. Lynch, S. Feller, T. D. Romo, K. Gawrisch, M. C. Pitman, P. H. Reggio, J. Biol. Chem. 285 (2010) 17954-17964.

[45] M. A. Tabrizi, P. G. Baraldi, G. Saponaro, A. R. Moorman, R. Romagnoli, D. Preti, S. Baraldi, E. Ruggiero, C. Tintori, T. Tuccinardi, F. Vincenzi, P. A. Borea, K.Varani, J. Med. Chem. 56 (2013) 4482-4496.

[46] E. Kotsikorou, F. Navas III, M. J. Roche, A. F. Gilliam, B. F. Thomas, H. H. Seltzman, P. Kumar, Z. H. Song, D. P. Hurst, D. L. Lynch, P. H. Reggio, J. Med. Chem. 56 (2013) $6593-6612$.

[47] A. Poso, J. W. Huffman, Br. J. Pharmacol. 153 (2008) 335-346.

[48] D. Wacker, G. Fenalti, M. A. Brown, V. Katritch, R. Abagyan, V. Cherezov, R. C. Stevens, J. Am. Chem. Soc. 132 (2010) 11443-11445.

[49] MODELLER, Program for Comparative Protein Structure Modelling by Satisfaction of Spatial Restraints, http://salilab.org/modeller

[50] M. A. Hanson, C. B. Roth, E. Jo, M. T. Griffith, F. L. Scott, G. Reinhart, H. Desale, B. Clemons, S. M. Cahalan, S. C. Schuerer, M. Sanna, G. W. Han, P. Kuhn, H. Rosen, R. C. Stevens, Science 335 (2012) 851-855.

[51] R. Lopez, ClustalWW - WWW Service at the European Bionformatics Institute, http://www.ebi.ac.uk/Tools/msa/clustalw2/, date of acces May 2013.

[52] Schrödinger, Mestro version 9.1 Schrödinger, LLC, New York 2009.

[53] J. A. Ballesteros, H. Weinstein, Methods Neurosci. 25 (1995) 366-428. 